\title{
Influence of the Microstructure and Silver Content on Degradation, Cytocompatibility, and Antibacterial Properties of Magnesium-Silver Alloys In Vitro
}

\author{
Zhidan Liu, ${ }^{1}$ Ronald Schade, ${ }^{2}$ Bérengère Luthringer, ${ }^{1}$ Norbert Hort, ${ }^{1}$ Holger Rothe, ${ }^{2}$ \\ Sören Müller, ${ }^{3}$ Klaus Liefeith, ${ }^{2}$ Regine Willumeit-Römer, ${ }^{1}$ and Frank Feyerabend ${ }^{1}$ \\ ${ }^{1}$ Institute for Material Research, Helmholtz-Zentrum Geesthacht, Max-Planck-Str. 1, 21502 Geesthacht, Germany \\ ${ }^{2}$ Institute for Bioprocessing and Analytical Measurement Techniques e.V. (iba), Rosenhof, 37308 Heilbad Heiligenstadt, Germany \\ ${ }^{3}$ Extrusion Research and Development Center, Chair Metallic Materials, TU Berlin, Gustav-Meyer-Allee 25, 13355 Berlin, Germany \\ Correspondence should be addressed to Frank Feyerabend; frank.feyerabend@hzg.de
}

Received 16 February 2017; Revised 28 April 2017; Accepted 8 May 2017; Published 22 June 2017

Academic Editor: Martin Kolisek

Copyright (c) 2017 Zhidan Liu et al. This is an open access article distributed under the Creative Commons Attribution License, which permits unrestricted use, distribution, and reproduction in any medium, provided the original work is properly cited.

\begin{abstract}
Implantation is a frequent procedure in orthopedic surgery, particularly in the aging population. However, it possesses the risk of infection and biofilm formation at the surgical site. This can cause unnecessary suffering to patients and burden on the healthcare system. Pure Mg, as a promising metal for biodegradable orthopedic implants, exhibits some antibacterial effects due to the alkaline $\mathrm{pH}$ produced during degradation. However, this antibacterial effect may not be sufficient in a dynamic environment, for example, the human body. The aim of this study was to increase the antibacterial properties under harsh and dynamic conditions by alloying silver metal with pure $\mathrm{Mg}$ as much as possible. Meanwhile, the $\mathrm{Mg}$-Ag alloys should not show obvious cytotoxicity to human primary osteoblasts. Therefore, we studied the influence of the microstructure and the silver content on the degradation behavior, cytocompatibility, and antibacterial properties of $\mathrm{Mg}-\mathrm{Ag}$ alloys in vitro. The results indicated that a higher silver content can increase the degradation rate of $\mathrm{Mg}$ - $\mathrm{Ag}$ alloys. However, the degradation rate could be reduced by eliminating the precipitates in the Mg-Ag alloys via T4 treatment. By controlling the microstructure and increasing the silver content, $\mathrm{Mg}-\mathrm{Ag}$ alloys obtained good antibacterial properties in harsh and dynamic conditions but had almost equivalent cytocompatibility to human primary osteoblasts as pure Mg.
\end{abstract}

\section{Introduction}

The clinical application of biodegradable implant and prosthesis has shown rapid growth to keep with the demands of a rapidly aging population. However, implant-associated orthopedic surgery infections are common postoperative wound infections and can cause biofilm formation on the implants or bones $[1,2]$. Biofilms are resistant to antibiotics and can protect bacteria from host immune mechanisms. Once a biofilm has formed, the only treatment is to remove the implant and the diseased tissue [3-5]. Prevention is the preferred method to address the growing problem of implant-associated infections $[6,7]$.

Pure magnesium (pure $\mathrm{Mg}$ ) and its alloys, as potential biodegradable implant materials, have the advantage of not requiring removal after bone tissue healing [8]. Therefore, infection caused by a second surgery can be avoided. In vitro, pure $\mathrm{Mg}$ exhibited some antibacterial properties due to its alkaline $\mathrm{pH}$ [9-11]. In the early stage of degradation, it can create an alkaline environment, which is adverse to the survival and reproduction of bacteria $[12,13]$. However, it is not clear whether these changes will occur in vivo, although it was shown that pure $\mathrm{Mg}$ induces osteoblasts and suppresses bacteria in a chronically infected rabbit tibial osteomyelitis model [14]. However, the length of time that an effective antibacterial concentration maintained in the local position is not sufficient, which will influence the resistance to infection and will affect osteomyelitis treatment $[14,15]$. One cause of these effects is that the degradation rate of pure $\mathrm{Mg}$ and magnesium alloys in vivo is lower than that in vitro 
[16-18]. In this case, a high $\mathrm{pH}$ cannot be maintained, so it sounds unrealistic for pure $\mathrm{Mg}$ or its alloys to achieve longterm inhibition to bacteria.

Silver (Ag) has effective antibacterial properties and has been used to treat burns and chronic wounds for centuries [19]. Silver nanoparticles (AgNPs) and silver ions can bind to proteins, change the membrane of bacteria, interfere with DNA expression, create reactive oxygen species (ROS), and affect thiol group compounds that exist in respiratory enzymes to inhibit respiratory processes [20-22]. The emergence of antibiotic-resistant strains of bacteria has promoted the use of metallic silver to prevent infections of indwelling devices [20]. There are cases of silver applications that focus on the antibacterial properties, for example, wound dressing, bone cement, and megaprosthesis [23-25]. Silvercoated megaprosthesis can release silver ions and reduce the infection rate compared to the group without silver [25]. In addition, metallic silver can stimulate osteogenic differentiation [26].

However, the accumulation of a high amount of silver in the human body can cause argyria or argyrosis, which results from the deposition of significant amounts of insoluble silver precipitates in the dermis of the skin and the cornea or conjunctiva of the eyes $[27,28]$. However, no pathological damage to tissues can be observed. The threshold amount of silver that can evoke argyria ranges from 3.8 to $5 \mathrm{~g}$ or even $10 \mathrm{~g}$ over the whole lifetime of adults [29]. The total body silver concentration that can cause argyria is $1 \mathrm{~g}$ for children under 10 years old [30]. Hence, the application of silver in the human body should consider these limitations. In clinical course, the amount of silver coated on megaprosthesis ranges from 0.4 to $1.69 \mathrm{~g}$ in adult patients [25]. However, no relevant evidence shows that such a low amount of silver in the human body or chronic silver exposure can cause pathological changes in any tissue or organ [27-29, 31]. Moreover, the loss of cell viability in vitro due to metallic silver or silver compounds is dose dependent [26, 32, 33]. Metallic silver has a lower risk of toxic effects compared with soluble silver compounds [34].

How to avoid or treat orthopedic implant contamination and biofilm formation is a complicated issue [35]. Novel, biodegradable magnesium alloys with antimicrobial properties are desirable considering the surgical contamination and appearance of multiresistance bacteria. Many methods have been studied, for example, coating and surface morphology, to endow permanent implants or even magnesium alloys the function of suppressing bacteria or reducing bacterial adhesion [20, 36-39]. However, maintaining long-term and stable prevention of implant-associated infection remains a problem [40]. In addition, the current methods cannot maintain the long-term antibacterial properties of biodegradable magnesium alloys.

In this study, metallic silver was alloyed with pure $\mathrm{Mg}$ so that the silver could be released continuously and react with bacteria if the bacteria attach to the surface of $\mathrm{Mg}$ - $\mathrm{Ag}$ alloy or the surrounding tissue during the whole degradation period. We planned to reach the best antibacterial properties of $\mathrm{Mg}$-Ag alloys by alloying silver inside as much as possible and obtain good cytocompatibility comparable to those of pure Mg by adjusting their microstructure via thermalmechanical processing and heat treatment. It is expected that biofilms cannot form on the $\mathrm{Mg}-\mathrm{Ag}$ alloy and surrounding tissue, even in a harsh environment with a large amount of bacteria and under flow conditions, for example, the human body. By this method, it is hoped that implant-associated and recurrent infections can be prevented successfully when $\mathrm{Mg}$ Ag alloy is used as a bone implant in the future.

\section{Material and Methods}

2.1. Materials Preparation. Magnesium (99.99wt\%, Xinxiang Jiuli Magnesium Co., Ltd., Xinxiang, China) and silver granules (99.99 wt\%, ESG Edelmetall-Handel GmbH \& Co. KG, Rheinstetten, Germany) were used for the preparation of Mg-6Ag and Mg-8Ag alloys. Pure magnesium was cut into small pieces and placed in a steel crucible with the corresponding amount ( $6 \mathrm{wt} \%$ or $8 \mathrm{wt} \%$ ) of silver. The metals were melted at $750^{\circ} \mathrm{C}$ under a protective atmosphere of $98 \% \mathrm{Ar}$ (argon) and 2\% $\mathrm{SF}_{6}$ (sulphur hexafluoride) and then stirred for 30 minutes at $200 \mathrm{rpm}$. After the temperature decreased to $730^{\circ} \mathrm{C}$, the melt was transferred to a permanent steel mould (diameter $\varnothing=120 \mathrm{~mm}$ ) that was coated inside with the mould release agent ALU-STOP LC25 (Büro für angewandte Mineralogie, Dr. Stephan Rudolph, Tönisvorst, Germany). The mould was held for $15 \mathrm{~min}$ at $680^{\circ} \mathrm{C}$ under a protective atmosphere and was then immersed in flowing room temperature water gradually at a speed of $100 \mathrm{~cm} / \mathrm{min}$ until the melted magnesium alloy solidified. Pure $\mathrm{Mg}$ ingots were recast into cylinder shape following the same solidification procedure. The tops and bottoms of the ingots with shrinkage and impurities were removed. The contents of elements in the Mg-Ag alloys were analyzed by X-ray fluorescence (Bruker AXS S4 Explorer, Bruker AXS $\mathrm{GmbH}$, Germany) and with a Spark Analyser (Spectrolab M, Spektro, Germany).

According to the $\mathrm{Mg}$-Ag phase diagram, silver has low solubility of $15 \mathrm{wt} \%$ in magnesium at eutectic temperature which is the lowest melting point of a mixture of components [41]. Homogenization treatment and hot extrusion were performed to acquire a homogeneous microstructure and stable mechanical properties. The homogenization treatment was conducted in a resistance furnace (Linn Elektro Therm AK 40. 06, Bad Frankenhausen, Germany) at $430^{\circ} \mathrm{C}$ for $16 \mathrm{~h}$, followed by quenching in room temperature water. The ingots were then heated up $\left(285^{\circ} \mathrm{C}\right.$ for $\mathrm{Mg}-6 \mathrm{Ag}$ and $300^{\circ} \mathrm{C}$ for Mg-8Ag) and processed by hot extrusion (Strangpresszentrum Berlin, Berlin, Germany), for which the extrusion ratio and the advance rate of stamp were 108 and $0.7 \mathrm{~mm} / \mathrm{s}$, respectively. The temperature of the container and steel die was $300^{\circ} \mathrm{C}$. The extruded rods $(\varnothing=12 \mathrm{~mm})$ were cut into discs $(\varnothing=10 \mathrm{~mm}$ and $h=1.5 \mathrm{~mm}$ ) (Henschel KG, Munich, Germany). T4 heat treatment (solution treatment) of the discs was conducted by placing them in a steel box filled with $\mathrm{Ar}$ and holding them in a resistance furnace (Vulcan $^{\mathrm{TM}}$ A-550, Dentsply Ceramco, USA) at $450^{\circ} \mathrm{C}$ for $8 \mathrm{~h}$ and before quenching. The discs were ground on sandpaper (2500\#, mesh) to remove the oxidation layer caused by heat treatment. 
2.2. Microstructure Analysis. Samples were prepared by grinding on sandpaper from 220\# to 2500\#, followed by polishing using water-free OPS (oxide polishing suspension) on a rubber plate. The samples were etched in picric solution (100 mL ethanol, $20 \mathrm{~mL}$ distilled water, 6-7 mL glacial acetic, acid and 12-15 g picric acid (99\%), all chemicals from SigmaAldrich Chemie, Taufkirchen, Germany) and were observed by polarized light microscopy (Leica 020-520.008 DM/LM, Wetzlar, Germany) and scanning electron microscopy (SEM, TESCAN vega 3 SBU, Brno, Czech Republic). The precipitates in the extruded $\mathrm{Mg}-\mathrm{Ag}$ alloy were characterized by Bruker X-ray diffraction (XRD).

2.3. Immersion Test. An optimized in vitro test setup was used for the immersion tests $[42,43]$. Cell culture medium (CCM), Dulbecco's Modified Eagle's Medium (DMEM), and GlutaMAX $+10 \%$ FBS (fetal bovine serum, PAA laboratories, Linz, Austria) were used for the immersion test and cell culture. The cell culture conditions were $5.0 \% \mathrm{CO}_{2}$, $20 \% \mathrm{O}_{2}, 37.0^{\circ} \mathrm{C}$, and $97.0 \% \mathrm{rH}$ (relative humidity). Discs were weighed by a Scaltec SBA32 (Scaltec, Goettingen, Germany) and sterilized ultrasonically in $70 \%$ ethanol solution for $30 \mathrm{~min}$. After drying, the discs were transferred to 12-well plates, which were filled with $2 \mathrm{~mL}$ CCM in each well, and then incubated in the cell culture conditions for 1 week. The old cell culture medium was replaced by a fresh one after 48 and 120 hours. After the immersion test was carried out for 168 hours, the degradation products were removed by chromic acid ( $180 \mathrm{~g} / \mathrm{L}$ in a. dest., Sigma-Aldrich Chemie, Taufkirchen, Germany). The discs were dried in a vacuum box and weighed by the precision electronic balance. The mean degradation rate was calculated using the previously described weight loss method [44].

2.4. Cytotoxicity Test. Human primary osteoblasts were selected for the cytotoxicity evaluation. The human primary osteoblasts came from patients undergoing total hip arthroplasty with local ethical committee agreement. Pure Mg and $\mathrm{Mg}$-Ag discs were sterilized ultrasonically in $70 \%$ ethanol solution for $30 \mathrm{~min}$. Extracts of pure $\mathrm{Mg}$ and $\mathrm{Mg}-\mathrm{Ag}$ for the MTT assay were prepared by immersing samples into CCM $(0.2 \mathrm{~g} / \mathrm{mL})$ for 3 days in the cell culture conditions. The concentration of $\mathrm{Mg}$, calcium (Ca), and Ag in the extracts was measured via inductively coupled plasma mass spectrometry (ICP-MS; Agilent 7700x ICP-MS, Waldbronn, Germany). The extracts were further characterized by measuring their $\mathrm{pH}$ and osmolality at room temperature using an ArgusX pH meter (Sentron, Roden, Netherlands) and a Gonotec 030-D cryoscopic osmometer (Gonotec, Berlin, Germany), respectively. A $50 \mu \mathrm{L}$ aliquot of CCM containing 2000 human primary osteoblasts was seeded into each well of 96-well plates. The plates were transferred to the incubator and kept in the cell culture conditions for 24 hours to ensure that the human primary osteoblasts attached to the bottom. The diluted pure $\mathrm{Mg}$ and $\mathrm{Mg}-\mathrm{Ag}$ extracts were prepared by adding CCM at ratios of $1: 5$ and $1: 10$. Then, the old CCM was replaced with fresh CCM (control group), pure Mg and $\mathrm{Mg}-\mathrm{Ag}$ extracts, and diluted extracts $(n=6$ for each concentration). After culturing for 3 days, $10 \mu \mathrm{L}$ 3-(4,5- dimethylthiazol-2-yl)-2,5-diphenyl-tetrazolium bromide solution (MTT) (Sigma-Aldrich, Steinheim, Germany) was added to each well and incubated for 4 hours. Then, $100 \mu \mathrm{L}$ SDS (sodium dodecyl sulphate) lysis buffer (Sigma-Aldrich Co., LLC, Steinheim, Germany) was added into the wells and incubated overnight. Finally, the values were measured using an ELISA multiwell plate reader (Tecan, Maennedorf, Switzerland) and the background value was removed.

In the adhesion test, pure $\mathrm{Mg}$ and $\mathrm{Mg}$ - $\mathrm{Ag}$ discs were placed in 12-well plates after the discs incubated in CCM in the cell culture conditions for 24 hours. A total of $10^{5}$ human primary osteoblasts were seeded on the surface of each disc. To ensure that the human primary osteoblasts attached to the surface, the seeded samples were kept in the incubator for $30 \mathrm{~min}$. Then, 12-well plates were slowly filled with $3 \mathrm{~mL}$ of fresh CCM and transferred into the incubator and cultured for 3,6 , or 9 days. The CCM was changed every 3 days. The $\mathrm{pH}$ and osmolality of the replaced medium were measured. Discs were washed gently in sterilized and distilled water and transferred into wells filled with LIVE/DEAD ${ }^{\circledR}$ Viability/Cytotoxicity Kit (Molecular Probes, Eugene, USA) according to the manufacturer's protocol. After incubation for $20 \mathrm{~min}$, the distribution and viability of human primary osteoblasts on pure $\mathrm{Mg}$ and $\mathrm{Mg}-\mathrm{Ag}$ discs were observed via fluorescent microscope (Nikon Eclipse Ti-S, Tokyo, Japan).

2.5. Biofilm Test and Evaluation. The biofilm test was conducted in a bioreactor system (Figure 1). This dynamic system has a cross-flow condition in the chambers, which ensures that the bacteria go through the surface of the discs. The flow rate of the medium in chamber was $0.3 \mathrm{~mL} / \mathrm{min}$. These conditions allow the possibility of initial biofilm formation on the discs [45]. During the running time of 15 hours, the temperature and $\mathrm{pH}$ were $37^{\circ} \mathrm{C}$ and 7.2 , respectively. All the parameters mentioned above were controlled by the bioreactor system (BioFlo ${ }^{\circledR} / \mathrm{CelliGen}^{\circledR} 115$ (New Brunswick $^{\mathrm{TM}}$ ), Eppendorf AG, New Brunswick, USA). Reference discs (titanium (Ti)) were always used as an internal control for the test. Pure $\mathrm{Mg}$ and $\mathrm{Mg}-\mathrm{Ag}$ alloys were treated with $25.0 \mathrm{kGy}$ gamma sterilization (BBF Sterilisationsservice $\mathrm{GmbH}$, Kernen, Germany) before the biofilm test [44]. The whole test was performed in a microaerophilic and sterilized environment to ensure bacterial activity. The bacteria culture medium (BCM) consisted of nutrient broth $(\mathrm{pH}=7.2), 3 \mathrm{~g}$ meat extract, $5 \mathrm{~g}$ peptone (Sigma-Aldrich Co., LLC, Steinheim, Germany), and $1 \mathrm{~L}$ distilled water. Phosphatebuffered saline ( $\mathrm{PBS}, \mathrm{pH}=7.4$ ) was prepared with $8 \mathrm{~g}$ $\mathrm{NaCl}, 0.2 \mathrm{~g} \mathrm{KCl}, 1.47 \mathrm{~g} \mathrm{Na}_{2} \mathrm{HPO}_{4}, 0.24 \mathrm{~g} \mathrm{KH}_{2} \mathrm{PO}_{4}$ (SigmaAldrich Co. LLC, Steinheim, Germany), and $1 \mathrm{~L}$ doubledistilled water.

Staphylococcus aureus (S. aureus, DSM number 20231) and Staphylococcus epidermidis (S. epidermidis, DSM number 3269) were used in the biofilm test. These bacteria are commonly found in implant-associated orthopedic infections or osteomyelitis [3,46-48], although there is contention about which is the most common bacteria isolated from clinical infections, especially implant-associated infections [49-51]. The bacteria were provided by the Leibniz Institute DSMZ-German Collection of Microorganisms and 


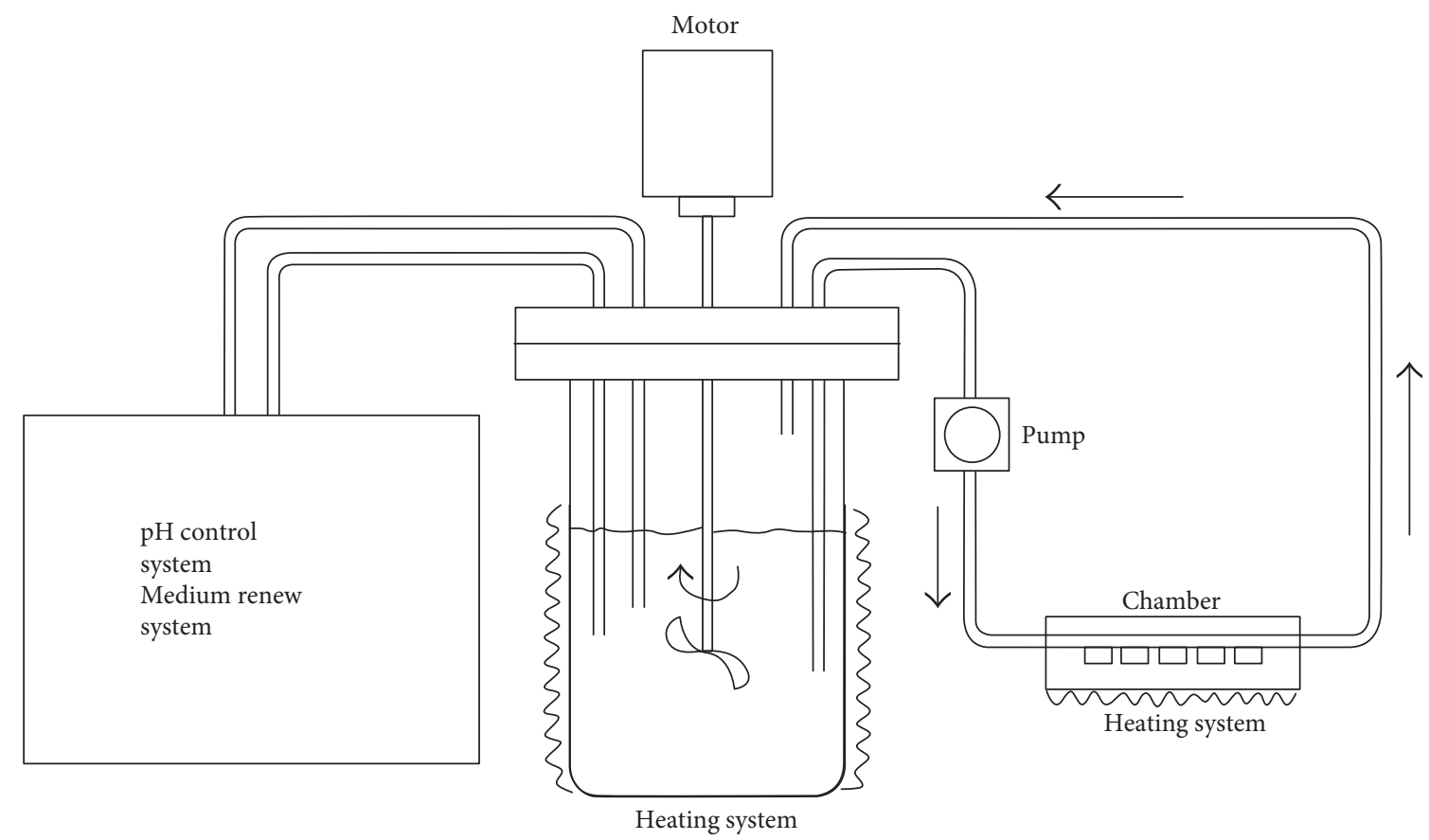

Figure 1: Schematic diagram of the bioreactor system.

Cell Cultures in Germany. The bacteria were cultured overnight and were mixed and imported into the bioreactor system after checking their viability. The density and ratio of the mixed bacteria in medium were $10^{6} / \mathrm{mL}$ and $1: 1$, respectively.

After the bioreactor system ran for 15 hours, all of the discs were removed from the chamber and labelled by adding LIVE/DEAD BacLight ${ }^{\mathrm{TM}}$ Bacterial Viability Kit (Thermo Fisher Scientific Inc. (Life Technologies), Eugene, USA). Some discs were observed by confocal laser scanning microscopy (CLSM, LSM 710, Carl Zeiss Microscopy GmbH, Jena, Germany). Images of the whole surface and the local details of the discs were taken by CLSM. The other discs $(n=12$ for each type of sample) were rinsed gently in distilled water, placed in glass bottles with PBS, and transferred to an ultrasonic bath (SONOREX SUPER 10P, BANDELIN electronic $\mathrm{GmbH} \&$ Co. KG, Berlin, Germany). A plastic scraper was used to remove the bacteria from the surfaces of the discs under sonication. The PBS solutions containing bacteria were diluted, placed on a counting chamber, and counted using a fluorescence microscope (BX51, Olympus Optical Co. (Europa) GmbH, Hamburg, Germany).

2.6. Sample Preparation for SEM and Generation of $3 D$ Images. In adhesion test, the procedures to prepare the SEM samples with human primary osteoblasts were fixation in $2.5 \%$ glutaraldehyde solution in buffer (Sigma-Aldrich Co. LLC, Steinheim, Germany) for 2 hours, staining in $1 \%$ osmium tetroxide (Sigma-Aldrich Co. LLC, Steinheim, Germany) for $30 \mathrm{~min}$, dehydration for 1 hour using increasing concentrations of 2-propanol (EMSURE ${ }^{\circledR}$, Darmstadt, Germany) (20\%, 40\%, 60\%, 80\%, and 100\%), and critical point drying (Leica EM CPD030, Bal-TEC AG, Balzers, Liechtenstein). Then, the samples were placed on an SEM sample
TABLE 1: Major and trace element composition of the Mg-Ag alloys.

\begin{tabular}{lccccc}
\hline Alloys & Ag wt\% & Fe wt\% & Cu wt\% & Ni wt $\%$ & Mg wt $\%$ \\
\hline Mg-6Ag & 6.26 & 0.00205 & 0.00100 & 0.00108 & Balance \\
Mg-8Ag & 8.51 & 0.00184 & 0.00104 & 0.00106 & Balance \\
\hline
\end{tabular}

holder with N650 Planocarbon (Plano GmbH, Wetzlar, Germany). In biofilm test, three-dimensional (3D) images of the discs were merged using SEM pictures with different tilt angles $\left(0^{\circ}, 7^{\circ}\right.$, and $\left.15^{\circ}\right)$ before and after removal of the degradation products.

2.7. Data Analysis. Statistical analyses were performed by one-way analysis of variance (ANOVA) in Origin 9.0G with the appropriate post hoc comparison test (Tukey's test). A $p$ value $<0.05$ was considered significant. The graphs present the results as the mean value with the standard deviation (SD) as the error bars.

\section{Results}

3.1. Metallography and Microstructure. The actual elemental composition of the Mg-Ag alloys is listed (Table 1). Pure Mg has a similar grain size as extruded Mg-6Ag. Extruded Mg-8Ag has finer grains (average grain size (AGS) $=7.9 \pm 4.5 \mu \mathrm{m}$ ) than extruded Mg-6Ag (AGS = 28.2 $\pm 13.4 \mu \mathrm{m})$. However, the grain size increased obviously after the T4 treatment and showed a nonuniform trend, but the microstructures of $\mathrm{Mg}-6 \mathrm{Ag}$ and Mg-8Ag became similar after T4 treatment (Figure 2). According to the XRD patterns, the precipitates in the extruded $\mathrm{Mg}$ $6 \mathrm{Ag}$ and $\mathrm{Mg}-8 \mathrm{Ag}$ are $\mathrm{Mg}_{54} \mathrm{Ag}_{17}$ (Figure 3(b)). Most of the precipitates are distributed along the grain boundaries of the extruded Mg-Ag alloys, as shown in the SEM images. There is a small amount of precipitate $(0.2 \%)$ in the extruded $\mathrm{Mg}-6 \mathrm{Ag}$ 

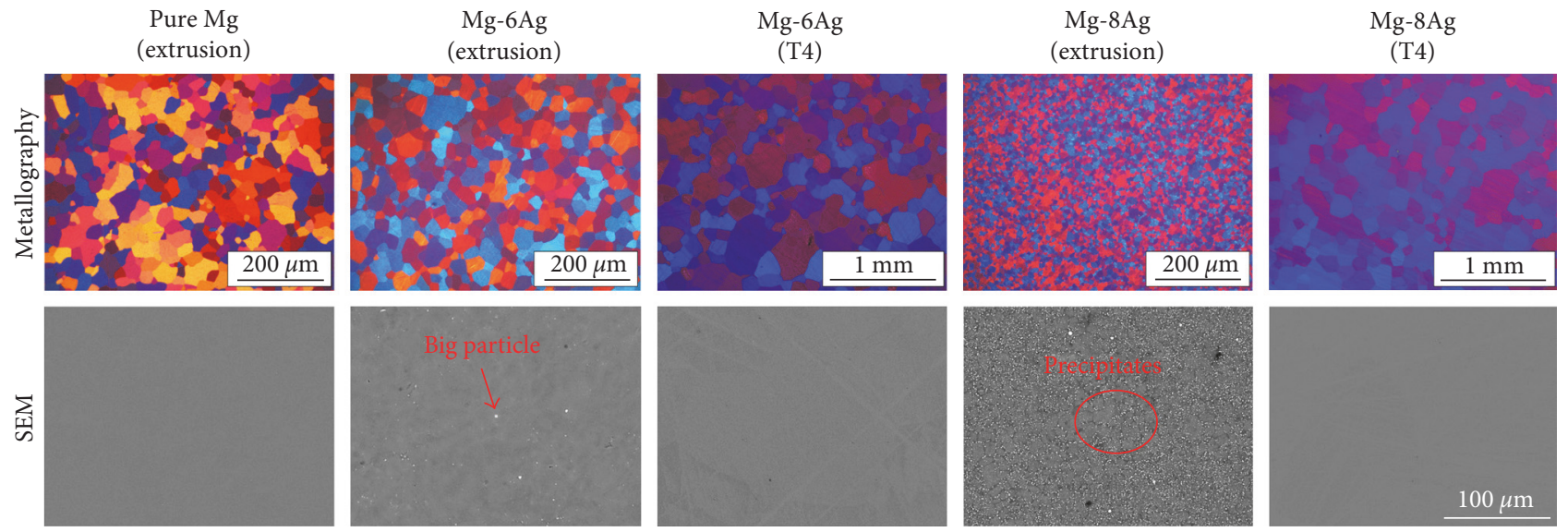

FIGURE 2: Metallography, distribution, and quantity of secondary phases and precipitates in the extruded Mg-Ag alloys before and after T4 treatment. The grain sizes of extruded pure Mg, extruded Mg-6Ag, T4-treated Mg-6Ag, extruded Mg-8Ag, and T4-treated Mg-8Ag are 29.9 $\pm 15.5,28.2 \pm 13.4,154.5 \pm 103.4,7.9 \pm 4.5$, and $159.9 \pm 89.7 \mu \mathrm{m}$, respectively. The SEM in BSE (back-scattered electron) mode was used. The ratios of second phases and precipitates in the extruded $\mathrm{Mg}-6 \mathrm{Ag}$ and $\mathrm{Mg}-8 \mathrm{Ag}$ are $0.2 \%$ and $2.3 \%$, respectively.
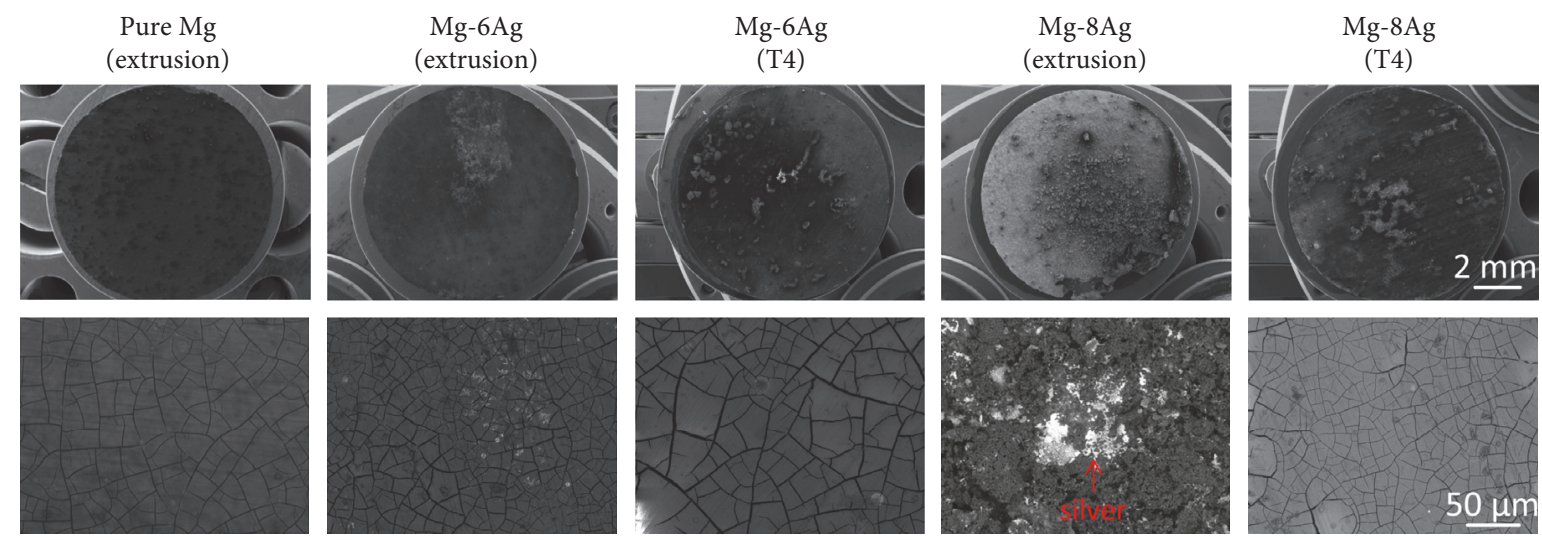

(a)

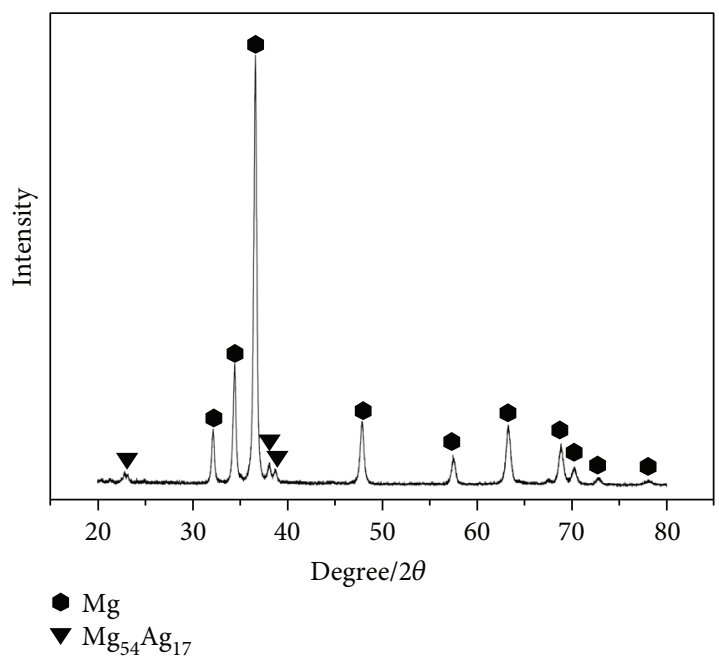

(b)

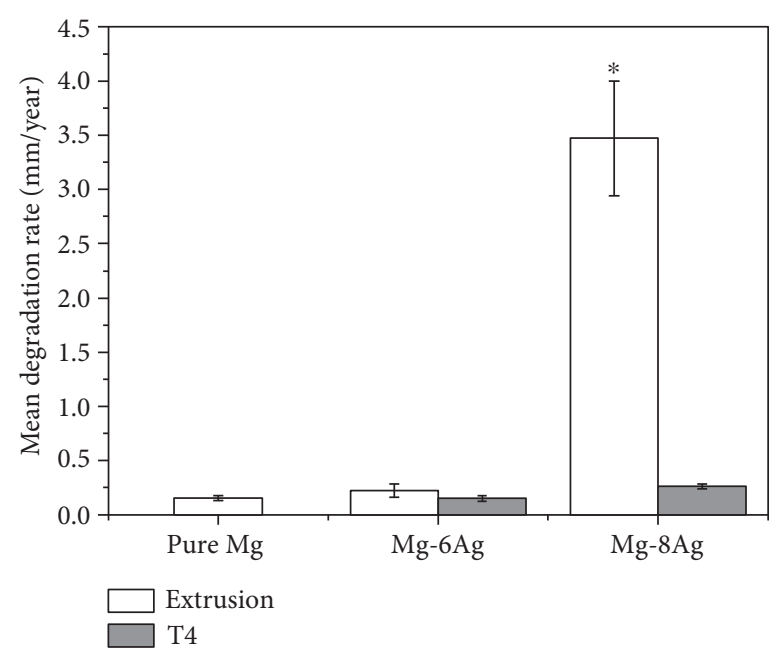

(c)

FIgure 3: (a) Surface morphology of discs after the immersion test. The images of the local details are in BSE mode. (b) XRD pattern of the extruded Mg-8Ag alloy. (c) The mean degradation rate of pure $\mathrm{Mg}$ and $\mathrm{Mg}$-Ag alloys in CCM in the cell culture conditions. The mean degradation rate of the extruded $\mathrm{Mg}-8 \mathrm{Ag}$ is significantly higher than the others. The "** indicates a significant difference compared with the other values, $p<0.05$. 
TABLE 2: Increments of $\mathrm{pH}$ and osmolality of pure $\mathrm{Mg}$ and $\mathrm{Mg}-\mathrm{Ag}$ alloys compared to those of CCM.

\begin{tabular}{lcc}
\hline Extracts & $\mathrm{pH}$ & Osmol/kg \\
\hline Pure Mg (extrusion) & 0.815 & 0.107 \\
Mg-6Ag (extrusion) & 0.920 & 0.110 \\
Mg-6Ag (T4) & 0.955 & 0.066 \\
Mg-8Ag (extrusion) & 0.895 & 0.104 \\
Mg-8Ag (T4) & 0.965 & 0.068 \\
\hline
\end{tabular}

and a large amount (2.3\%) in the extruded Mg-8Ag. Some larger particles can be found in the extruded $\mathrm{Mg}-6 \mathrm{Ag}$ and $\mathrm{Mg}-8 \mathrm{Ag}$ that are residuals of the secondary phase after the homogenization treatment of the ingots. After T4 treatment, nearly all the secondary phases and precipitates in the extruded $\mathrm{Mg}-\mathrm{Ag}$ alloys dissolved into the alloys.

3.2. Morphology and Degradation Rate. After the immersion test, the surface condition of the discs can be observed (Figure 3(a)). Some black or white dots, which are degradation products, are present on the surface of the pure $\mathrm{Mg}$ and $\mathrm{Mg}-\mathrm{Ag}$ alloys in low-magnification images. However, the extruded $\mathrm{Mg}$-8Ag disc showed more severe degradation than the other discs. Loose degradation products and accumulated silver are observed on the surface. There is also some accumulated silver on the surface of the extruded Mg-6Ag disc. However, there are only cracks on the pure $\mathrm{Mg}$ and $\mathrm{T} 4$-treated $\mathrm{Mg}$-Ag discs after the degradation layer is dehydrated.

The addition of silver led to a slight increase in the degradation rate of $\mathrm{Mg}-6 \mathrm{Ag}$ alloy compared to pure $\mathrm{Mg}$ (Figure 3(c)). A further increase in silver significantly enhanced the degradation to $3.47 \mathrm{~mm} /$ year. This effect could be drastically reduced by $\mathrm{T} 4$ treatment, which led to degradation rates of less than $0.5 \mathrm{~mm} /$ year. In this case, the degradation rate increased linearly with the amount of silver.

\subsection{Cytocompatibility}

3.3.1. MTT. The $\mathrm{pH}$ and osmolality of the extracts from the pure $\mathrm{Mg}$ and extruded $\mathrm{Mg}$-Ag alloys were elevated compared to the CCM (Table 2). More Mg existed in the extracts than in CCM, but the concentration of $\mathrm{Ca}$ in the extracts decreased (Table 3). Magnesium/calcium phosphates formed in the degradation layer during degradation [52-55]. After T4 treatment, the osmolality of the Mg-Ag alloy extracts was lower than that of the pure $\mathrm{Mg}$ and extruded $\mathrm{Mg}-\mathrm{Ag}$ extracts. The concentrations of $\mathrm{Mg}, \mathrm{Ca}$, and $\mathrm{Ag}$ in the primary extracts from extruded $\mathrm{Mg}$ - $\mathrm{Ag}$ were higher than those from T4-treated Mg-Ag.

In the MTT assay, all primary extracts, including pure $\mathrm{Mg}$ extract, showed cytotoxicity compared with CCM because of high $\mathrm{pH}$ and osmolality (Figure 4). Their values were below the cytotoxic limit of $75 \%$ cell viability. After fivefold dilution, most of the extracts did not show cytotoxicity, except for the extract of the extruded $\mathrm{Mg}$ $8 \mathrm{Ag}$, which also did not reach the level of $75 \%$ because the silver concentration was still higher than the tolerance
TABLE 3: Calculated concentrations of elements in the extracts of extruded pure $\mathrm{Mg}$ and $\mathrm{Mg}$ - $\mathrm{Ag}$ alloys.

\begin{tabular}{lcccc}
\hline \multirow{2}{*}{ Extracts } & \multirow{2}{*}{ Dilution } & \multicolumn{3}{c}{ Concentration $(\mathrm{mg} / \mathrm{L})$} \\
& 1 & 1210 & 27 & $<0.1$ \\
Pure Mg (extrusion) & $1 / 5$ & 258 & 65.4 & $<0.1$ \\
& $1 / 10$ & 139 & 70.2 & $<0.1$ \\
& 1 & 1280 & 26 & 1.2 \\
Mg-6Ag (extrusion) & $1 / 5$ & 272 & 65.2 & 0.24 \\
& $1 / 10$ & 146 & 70.1 & 0.12 \\
Mg-6Ag (T4) & 1 & 1010 & 17 & 0.31 \\
& $1 / 5$ & 218.8 & 62.6 & 0.062 \\
& $1 / 10$ & 119.9 & 68.3 & 0.031 \\
Mg-8Ag (extrusion) & 1 & 1150 & 25 & 104 \\
& $1 / 5$ & 246 & 65 & 20.8 \\
& $1 / 10$ & 133 & 70 & 10.4 \\
Mg-8Ag (T4) & 1 & 930 & 15 & 0.64 \\
& $1 / 5$ & 202.8 & 62.2 & 0.128 \\
Cell culture medium (CCM) & $1 / 10$ & 111.9 & 68.1 & 0.064 \\
\end{tabular}

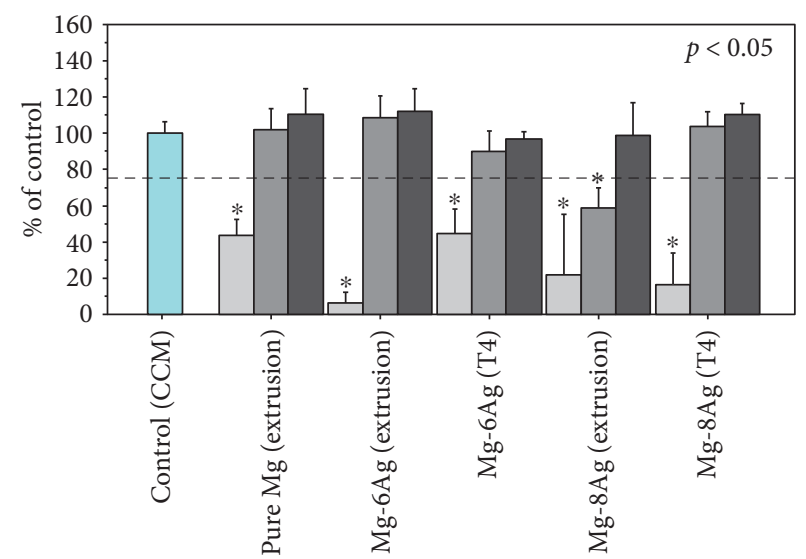

Cell culture medium and extracts

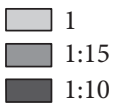

FIgURE 4: Viability of human primary osteoblasts determined by MTT assay in the primary, 1:5, and 1:10 extracts. The dotted line marks $75 \%$ cell viability, which indicates no potential cytotoxicity [58]. The "*” indicates statistically significant difference at $p<0.05$ versus the control group (CCM).

of human primary osteoblasts. After fivefold and tenfold dilutions, the extract from T4-treated Mg-8Ag showed good cytocompatibility as did the diluted pure $\mathrm{Mg}$ extracts and CCM, although all primary extracts exhibited cytotoxicity to human primary osteoblasts.

3.3.2. Live/Dead Staining and Adhesion Test. The $\mathrm{pH}$ and osmolality were measured after preincubation for 24 hours and culturing human primary osteoblasts on the samples 


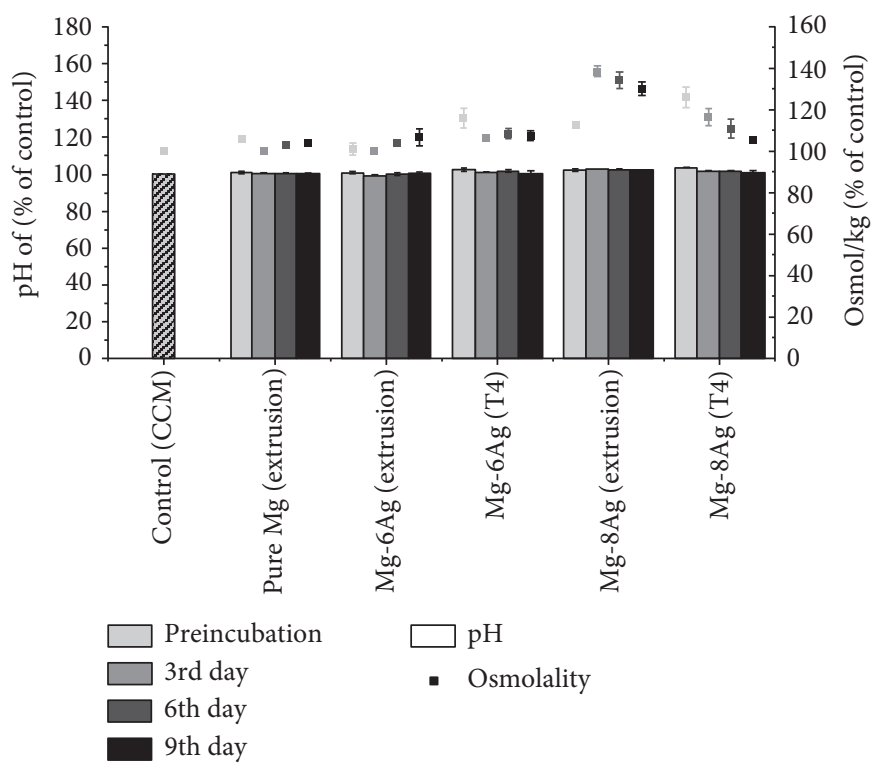

(a)

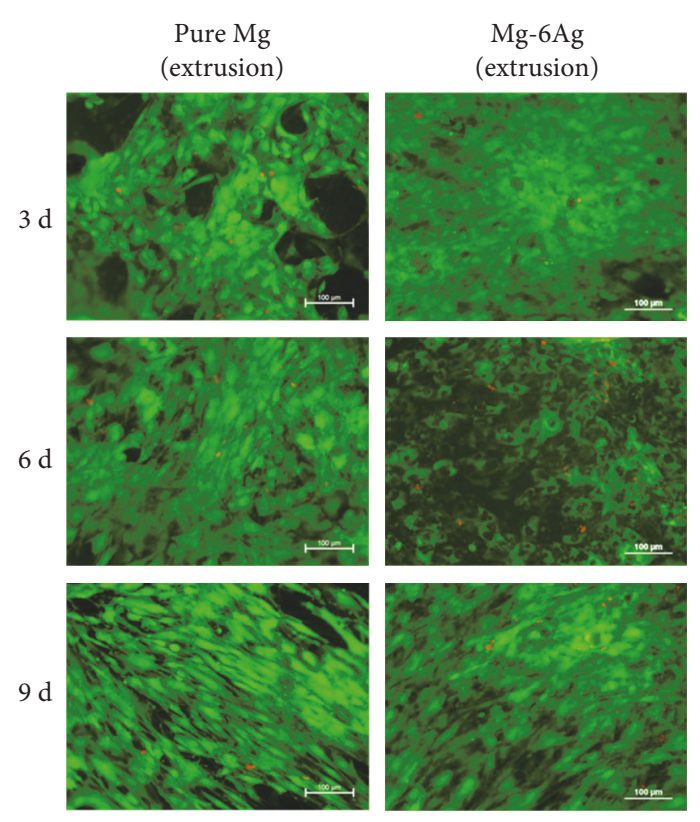

Extrusion

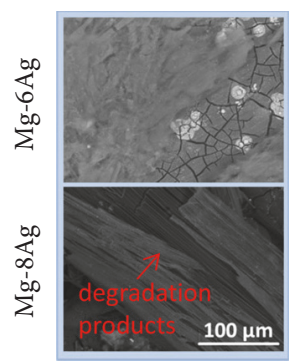

Mg-6Ag

(T4)
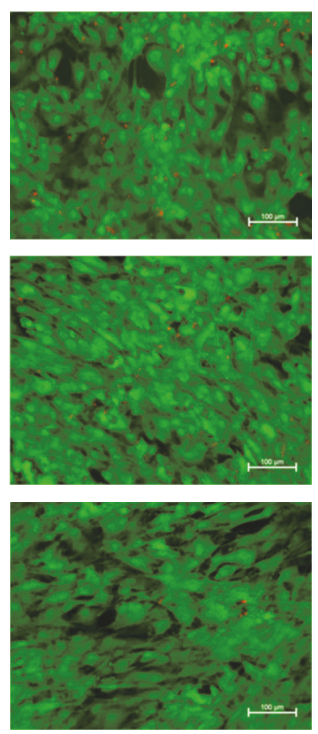

(b)

T4

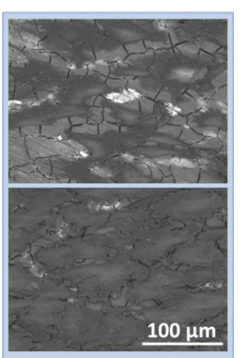

(c)
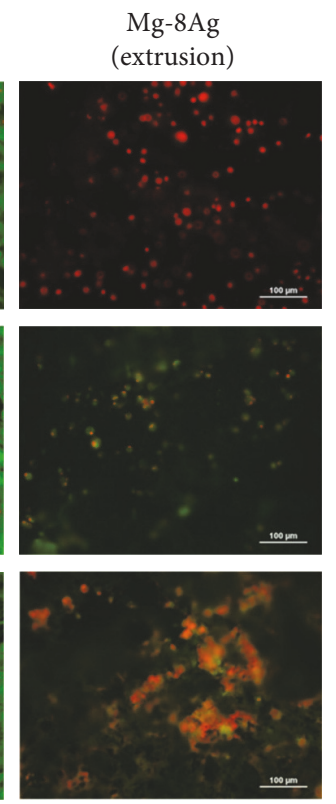

$\mathrm{T} 4$

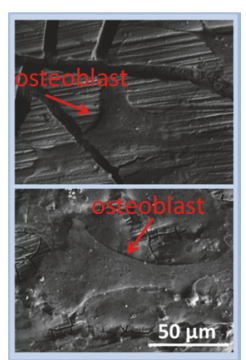

$\mathrm{Mg}-8 \mathrm{Ag}$

(T4)
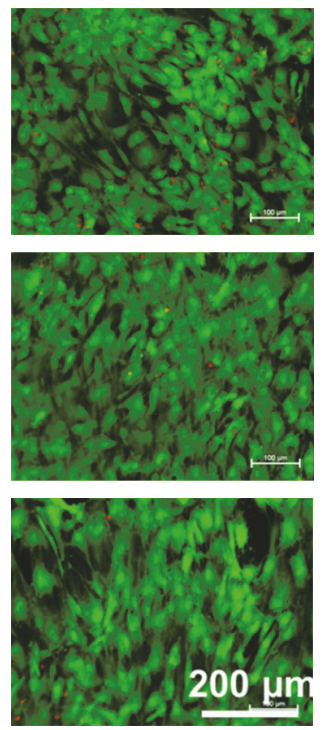

FIGURE 5: (a) Variation of $\mathrm{pH}$ and osmolality during the incubation. (b) Live/dead staining of human primary osteoblasts on pure Mg and Mg-Ag alloys. The clear green parts represent living osteoblasts and the red dots dead osteoblasts. (c) SEM images of the adhesion tests of human primary osteoblasts. The first and second vertical rows show thick cell layers covering the surface after 9 days. The third vertical row shows the status of a single osteoblast attached to the degradation layer after 3 days. 


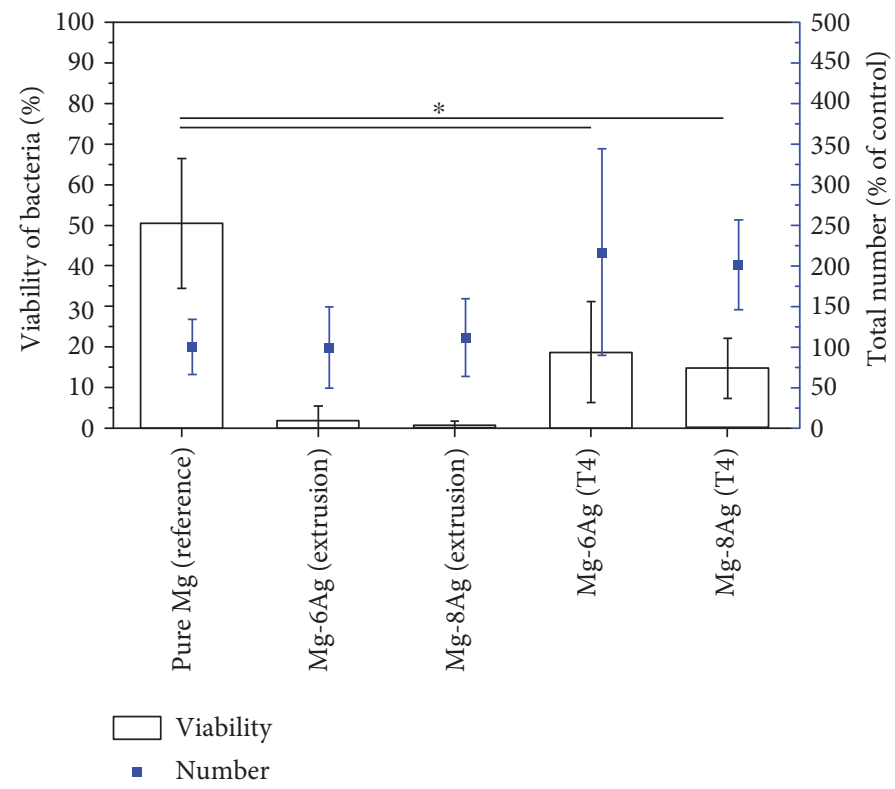

Figure 6: Viability of bacteria and total bacteria on the discs. From left to right-extruded pure Mg, extruded Mg-Ag alloys and T4-treated $\mathrm{Mg}$-Ag alloys after extrusion. Pure $\mathrm{Mg}$ is the reference for the total number of bacteria. The "*” means that pure Mg has a statistically significant difference in viability at $p<0.05$ versus $\mathrm{T} 4$-treated $\mathrm{Mg}$ - $\mathrm{Ag}$ discs.

for 3, 6, and 9 days. The $\mathrm{pH}$ of the pure $\mathrm{Mg}$ and T4-treated $\mathrm{Mg}-\mathrm{Ag}$ discs decreased gradually over time (Figure 5(a)). The osmolality of the extract from pure $\mathrm{Mg}$ was stable, and the osmolality of the extract from extruded $\mathrm{Mg}-6 \mathrm{Ag}$ increased slightly over time. However, the osmolality of the extract from extruded $\mathrm{Mg}-8 \mathrm{Ag}$ remained at a high level after preincubation, and it had nearly the highest $\mathrm{pH}$ and osmolality at all time points. The extracts of the T4-treated Mg-Ag discs had higher osmolality after preincubation, but the osmolality decreased rapidly over time.

The regions with the same cell density were selected for comparison after live/dead staining (Figure 5(b)). The degradation rates of the extruded pure $\mathrm{Mg}$ and $\mathrm{Mg}-6 \mathrm{Ag}$ were much lower than those of the extruded Mg-8Ag in CCM in the cell culture conditions according to the $\mathrm{pH}$ and osmolality (Figure 5(a)). Human primary osteoblasts can survive and attach to extruded pure $\mathrm{Mg}$, extruded $\mathrm{Mg}-6 \mathrm{Ag}$, and $\mathrm{T} 4$ treated $\mathrm{Mg}-6 \mathrm{Ag}$ discs. After 3 days, on pure $\mathrm{Mg}$ and $\mathrm{Mg}$ $6 \mathrm{Ag}$, some dead osteoblasts were detected. After 6 days, the number of dead osteoblasts decreased. After 9 days, no differences were detected between the viability of human primary osteoblasts on pure $\mathrm{Mg}$ and $\mathrm{Mg}-6 \mathrm{Ag}$ discs. However, the extract from the extruded Mg-8Ag always had the highest average $\mathrm{pH}$ and osmolality, which indicates a faster degradation rate. The $\mathrm{pH}$ and osmolality near the surface of the extruded Mg-8Ag discs were higher, so many bubbles formed on the surface and a large amount of silver was released. As a result, no human primary osteoblasts attached to and survived on the extruded $\mathrm{Mg}-8 \mathrm{Ag}$ discs. After T4 treatment, the $\mathrm{pH}$ and osmolality of $\mathrm{Mg}-8 \mathrm{Ag}$ discs were lower and showed better cytocompatibility than before. Human primary osteoblasts can attach and proliferate on T4-treated $\mathrm{Mg}-8 \mathrm{Ag}$ discs as well as on pure $\mathrm{Mg}$ and $\mathrm{Mg}-6 \mathrm{Ag}$ discs, but a slightly higher amount of dead cells was observed in the initial stage (after 3 days). Cell layers and the details of human primary osteoblasts could be observed on all surfaces of the $\mathrm{Mg}-\mathrm{Ag}$ discs, except for the extruded Mg-8Ag disc, where there are only degradation products (Figure 5(c)).

\subsection{Biofilm Test}

3.4.1. Viability of Bacteria. The extruded Mg-Ag alloys showed the best antibacterial effect (Figure 6). The viability of bacteria was much lower on the $\mathrm{Mg}$-Ag alloys than on pure $\mathrm{Mg}$. There was a relative high viability of bacteria on pure $\mathrm{Mg}$ of $50.35 \%$. However, the viability on T4-treated Mg-6 Ag and Mg-8Ag discs was $18.64 \%$ and $14.75 \%$, respectively, which was significantly lower than that on pure $\mathrm{Mg}$. In addition, more bacteria were observed on T4-treated Mg-Ag discs than on the extruded $\mathrm{Mg}-\mathrm{Ag}$ discs.

3.4.2. Biofilm Culture. In the biofilm test, incubation for 15 hours can form an initial biofilm on Ti discs, which were set as the negative control for internal evaluation. A nearly complete young biofilm can be observed on the Ti disc (Figure 7(a)). A large amount of live bacteria on Ti disc could be observed in the high-magnification images (Figure 7(b)). The total amount of bacteria on pure $\mathrm{Mg}$ is obviously lower than on Ti disc. Extruded Mg-Ag discs showed local pitting degradation and had a faster degradation rate in BCM with a constant $\mathrm{pH}$ (7.2) than in CCM (Figure 7(a)). Many dead bacteria were present on the extruded $\mathrm{Mg}-\mathrm{Ag}$ discs based on the overview pictures. However, the overview of the biofilm showed no obvious difference between pure $\mathrm{Mg}$ and T4-treated Mg-Ag discs. By judging from the highmagnification images (Figure 7(b)), details of live and dead bacteria on the T4-treated $\mathrm{Mg}$ - $\mathrm{Ag}$ alloys were shown. Most of the bacteria on the surface of the T4-treated Mg-Ag discs were dead compared to the bacteria on pure $\mathrm{Mg}$. 


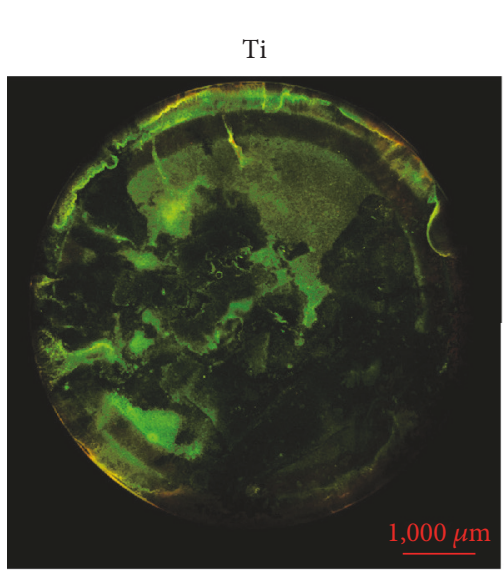

Pure Mg (extrusion)
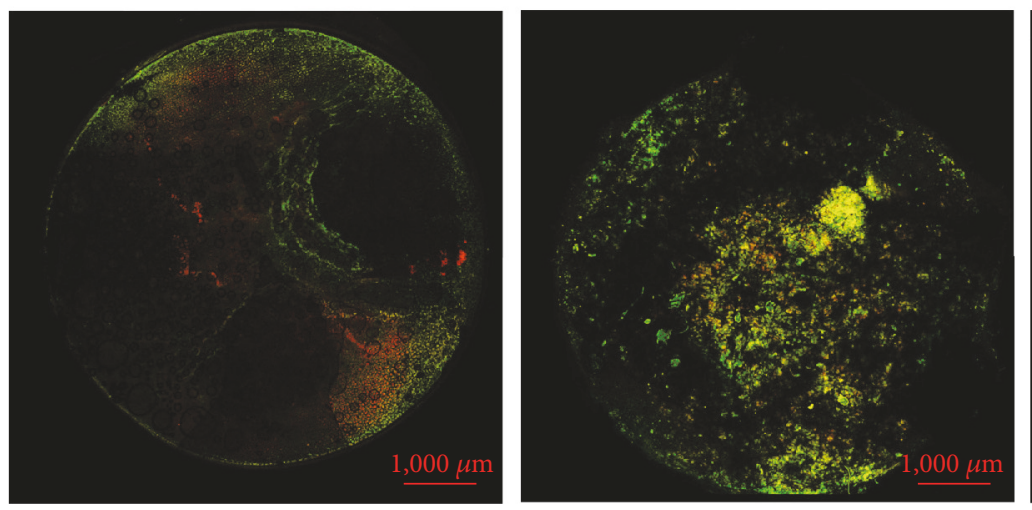

(a)

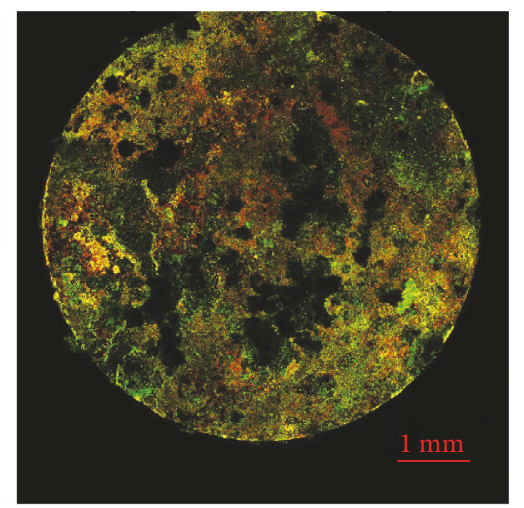

$\mathrm{Mg}-6 \mathrm{Ag}$

(T4)

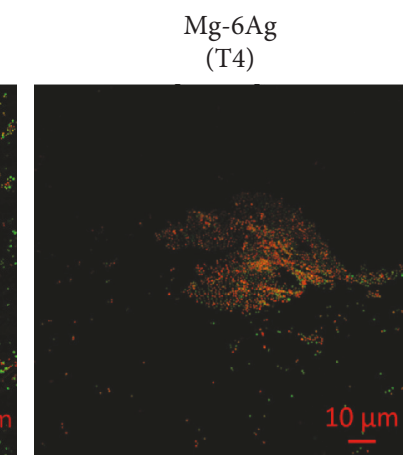

$\mathrm{Mg}-6 \mathrm{Ag}$

Pure Mg
(extrusion)

$\mathrm{Ti}$

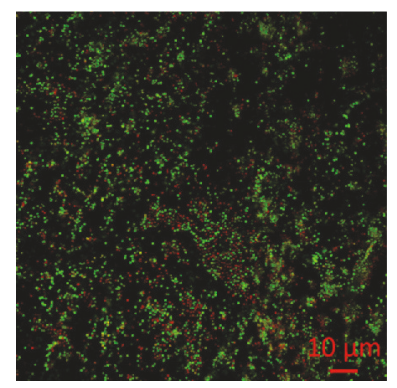

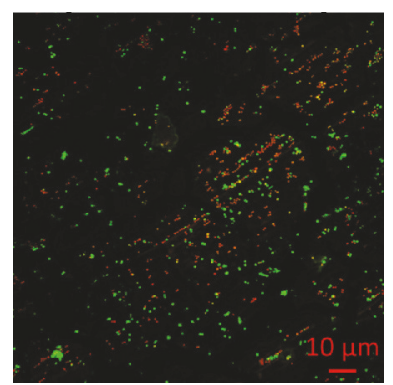

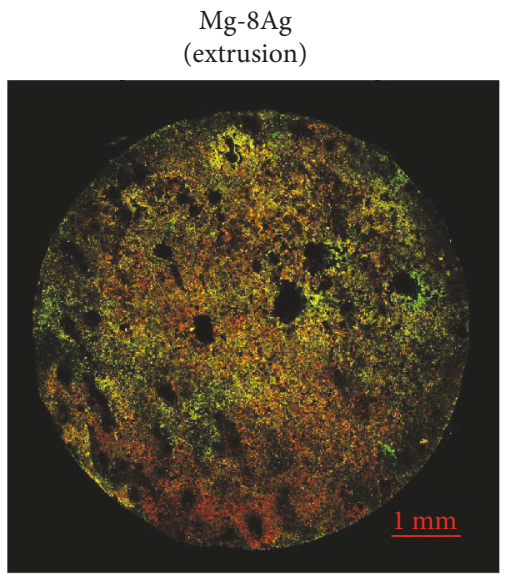

Mg-8Ag

(T4)

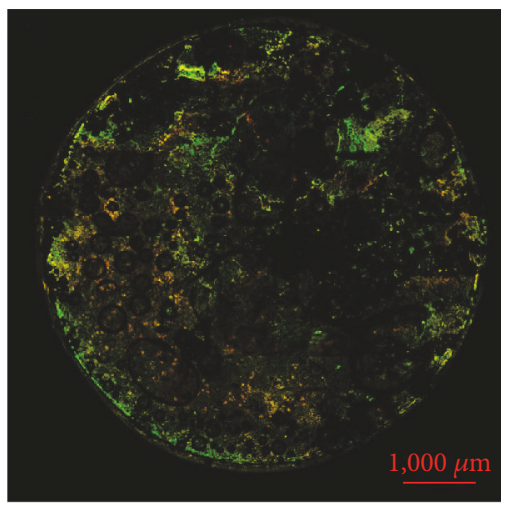

Mg-8Ag

(T4)

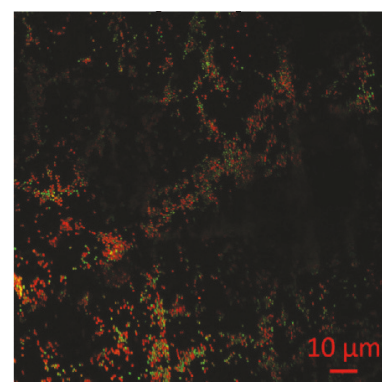

(b)

Figure 7: (a) Overview of biofilm formation. (b) Details of bacteria on discs.

3.4.3. Surface Morphology after the Biofilm Test in the Flow System. The 3D images of pure $\mathrm{Mg}$ and T4-treated MgAg discs before and after removal of the degradation products are shown (Figure 8). The surfaces of the discs with degradation products appear coarse. It can be observed that many degradation products are present on the surface of the pure $\mathrm{Mg}$ and $\mathrm{Mg}-\mathrm{Ag}$ discs. There are also some needle-like crystals on the T4-treated $\mathrm{Mg}-6 \mathrm{Ag}$ disc and many needle-like crystals on the T4-treated Mg$8 \mathrm{Ag}$ disc, so they look very rough in the $3 \mathrm{D}$ images. However, after removal of degradation products, the peaks disappeared and many degradation pits were revealed, especially on pure $\mathrm{Mg}$, where a porous surface was exposed. However, only shallow and broad pits were observed on the surface of T4-treated Mg-Ag discs, which indicates a more homogeneous degradation mechanism. The average roughness (Sa) of pure $\mathrm{Mg}$, T4-treated $\mathrm{Mg}$ $6 \mathrm{Ag}$, and T4-treated $\mathrm{Mg}-8 \mathrm{Ag}$ are $8.68 \pm 0.8,6.42 \pm 0.42$, and $8.88 \pm 1.92$, respectively, and the developed interfacial areas $(\mathrm{Sdr})$ are $37.87 \pm 1.44,19.26 \pm 2.72$, and $22.39 \pm 2.23$, respectively. Therefore, the Sa of pure $\mathrm{Mg}$ and $\mathrm{T} 4$-treated $\mathrm{Mg}-\mathrm{Ag}$ alloys is on the same level, and the Sdr of the T4-treated Mg-Ag alloys is significantly lower than that of the pure $\mathrm{Mg}$ at $p<0.05$. Therefore, the T4-treated $\mathrm{Mg}$-Ag alloys have less contact area with the medium than pure $\mathrm{Mg}$ during degradation. 


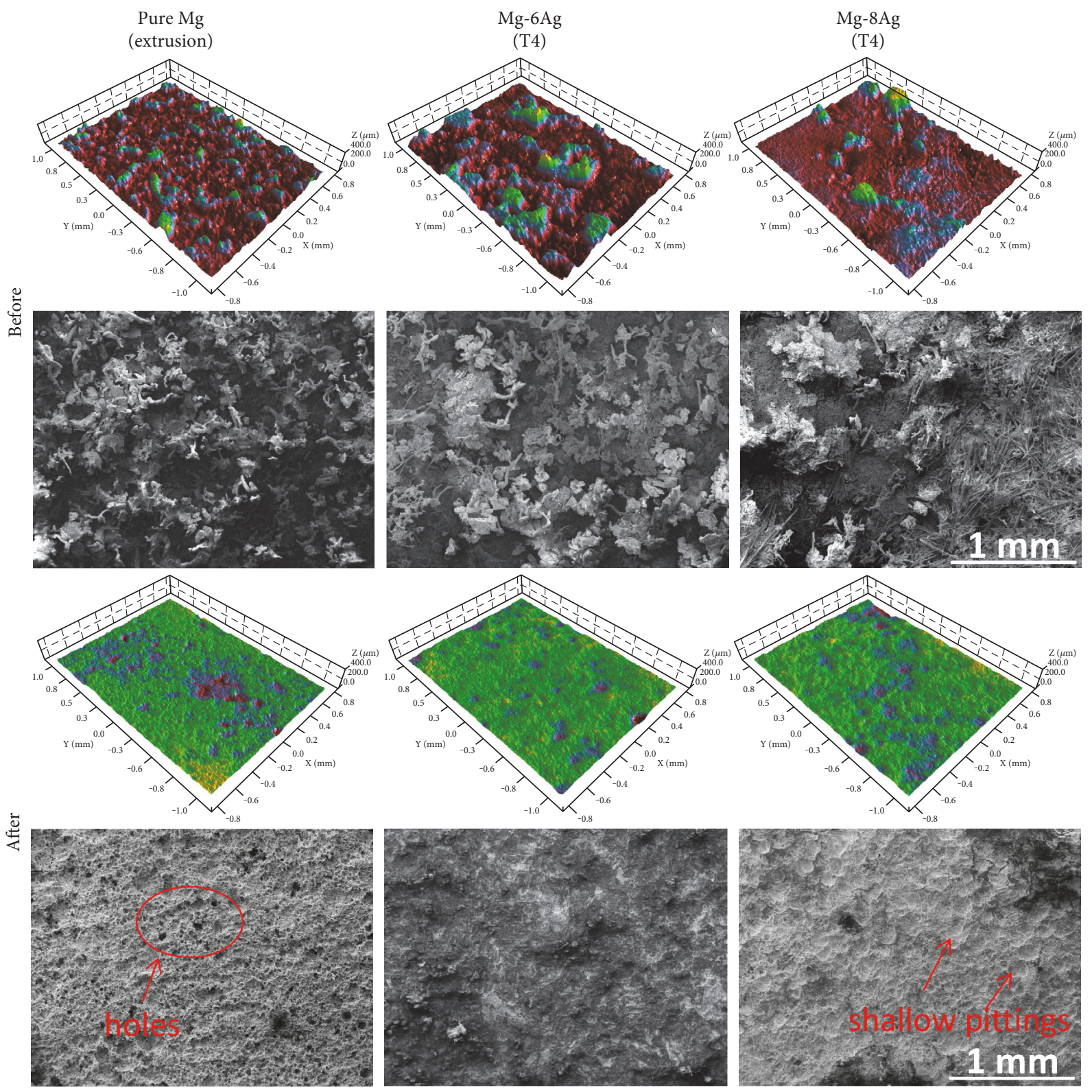

FIGURE 8: 3D images and surface conditions (SEM) before and after removal of the degradation products. The average roughness (Sa) of pure $\mathrm{Mg}, \mathrm{Mg}-6 \mathrm{Ag}$, and $\mathrm{Mg}-8 \mathrm{Ag}$ are $8.68 \pm 0.8,6.42 \pm 0.42$, and $8.88 \pm 1.92$, respectively. The developed interfacial areas (Sdr) are $37.87 \pm 1.44$, $19.26 \pm 2.72$, and $22.39 \pm 2.23$.

\section{Discussion}

Silver release plays a key role in eliminating multiple bacteria and preventing biofilm formation [23]. The novel point is that the addition of silver to pure $\mathrm{Mg}$ significantly improved the antibacterial effect in a dynamic environment because silver was released from the matrix continuously during the whole degradation of $\mathrm{Mg}$-Ag alloy as an orthopedic implant. In a previous study with cast material, the effect of silver addition could already be demonstrated [56]. However, cast magnesium alloys would never be used to produce implants. Therefore, in this study, extruded Mg-Ag alloys were evaluated. Extrusion generally led to a finer microstructure and was associated with lower degradation rates, imbalancing the silver release. Therefore, we evaluated higher silver contents in this study. We found that Mg-Ag alloys possessed much higher degradation rates when the silver content reached in magnesium $8 \mathrm{wt} \%$. The high $\mathrm{pH}$, osmolality, and silver concentration had negative effects on the viability of human primary osteoblasts, although good antibacterial properties were shown in dynamic conditions. T4 heat treatment decreased the degradation of $\mathrm{Mg}$-Ag alloys. As a result, human primary osteoblasts could survive on the surface of T4-treated Mg-Ag alloys. Meanwhile, the Mg-Ag alloys still had a much better antibacterial effect than pure $\mathrm{Mg}$.

Silver has a major influence on the degradation behavior of Mg-Ag alloys. Since it has low solubility in magnesium at ambient temperature [41], more secondary phases 
or precipitates exist in $\mathrm{Mg}-\mathrm{Ag}$ alloys when the silver content is higher [56]. Both the amount and distribution of precipitates can affect the degradation behavior due to the principle of microgalvanic corrosion $[12,54]$. The degradation rate increases linearly with increasing quantity of precipitates and the precipitates can cause localized degradation phenomenon [57]. For example, the extruded $\mathrm{Mg}-8 \mathrm{Ag}$ had higher degradation rate than the extruded Mg-6Ag. T4 treatment near the eutectic temperature can eliminate the secondary phases and precipitates. Since the $\mathrm{Mg}_{54} \mathrm{Ag}_{17}$ precipitates did not have the ability to restrict the migration of grain boundaries at high temperature, the grains were enlarged during T4 treatment. The elimination of precipitates weakened galvanic corrosion, so the degradation rate decreased [12]. For pure Mg and T4-treated Mg-Ag alloys, they had different grain sizes and both of them had no precipitates inside. T4-treated Mg-6Ag had nearly the same degradation rate compared to pure Mg. T4-treated Mg-6Ag had bigger grains than pure $\mathrm{Mg}$, so grain size was not the key factor to influence the degradation rate. T4-treated $\mathrm{Mg}$-6 Ag and T4-treated Mg$8 \mathrm{Ag}$ had no significant difference of grain size. However, T4treated $\mathrm{Mg}$-8Ag had higher degradation rate than T4-treated Mg-6Ag to some extent. In this case, solid solution of silver in magnesium influenced the degradation rate when it reached $8 \mathrm{wt} \%$. The pure $\mathrm{Mg}$ and T4-treated Mg-Ag alloys had lower degradation rates than the extruded $\mathrm{Mg}-\mathrm{Ag}$ alloys in CCM. T4-treated Mg-Ag alloys had more homogeneous and flatter degradation surfaces and lower pitting degradation trends than pure $\mathrm{Mg}$ in the flow chamber according to the $3 \mathrm{D}$ images, even though the low $\mathrm{pH}$ (7.2) of BCM had an adverse effect on the stability of the degradation layer [57]. The morphology difference was related to the solution of silver and microstructural changes via T4 treatment. Hence, the existence of precipitates mainly influenced the degradation behavior followed by solution of silver rather than grain size.

The degradation rate of $\mathrm{Mg}$-Ag alloys can influence the $\mathrm{pH}$ and osmolality of the medium and silver release, which are closely related to cytocompatibility [43]. A high degradation rate largely leads to increased $\mathrm{pH}$, osmolality, hydrogen generation and silver release. However, the $\mathrm{pH}$ will not always increase linearly with the degradation rate because of a "saturation effect". The increment of osmolality is because of $\mathrm{Mg}$ ion release instead of $\mathrm{Ca}$ and other ions. According to the MTT and adhesion test, high pH, osmolality, and silver contents can cause cytotoxicity to human primary osteoblasts, for example, extruded $\mathrm{Mg}-8 \mathrm{Ag}$. It is also not easy for cells or bacteria to attach to the surface due to the hydrogen generation, although good antibacterial properties can be obtained. For pure $\mathrm{Mg}$, the cytotoxicity of the primary extract is caused by the high $\mathrm{pH}$ and osmolality. Similarly, pure magnesium cannot rely on a high $\mathrm{pH}$ to achieve its antibacterial effect, regardless of cytotoxicity, because high osmolality or magnesium ion concentration causes osmotic shock in human cells [58]. Therefore, a high degradation rate is not required of magnesium alloys used as orthopedic implants, and the degradation rate should be controlled to meet the cytotoxicity criteria first.

The biofilm assay was conducted under flowing conditions. The in vitro design of the dynamic system with large numbers of bacteria in the flowing medium represents harsh conditions, although the in vivo conditions normally show clearly lower bacteria concentrations. The flowing conditions and $\mathrm{pH}$ control system can exclude the $\mathrm{pH}$ effect of the corroding $\mathrm{Mg}$ alloys as much as possible. Pure $\mathrm{Mg}$ did not show satisfactory antibacterial properties under these conditions. Based on the viability of bacteria on pure $\mathrm{Mg}$ discs, there are still considerable numbers of live bacteria that should not be neglected. From the overview of the biofilm and bacteria distribution on the discs, it appears that pure $\mathrm{Mg}$ has the potential to form many colonies or a biofilm layer under suitable conditions, although the total amount of bacteria is less than that on the negative control groups [59]. Admittedly, the $\mathrm{pH}$ plays an important antibacterial role due to the alkaline environment created during degradation [9-11]. The alkaline environment has adverse effects on bacteria in static conditions. It is unclear whether pure $\mathrm{Mg}$ has sufficient antibacterial properties in these conditions in a dynamic environment, such as the human body.

There was a large amount of silver released from the extruded Mg-Ag alloys because of high degradation rate. As a result, they showed good antibacterial properties. However, the viability of bacteria was not as low as expected, for example, $99.9 \%$. One reason is that a large portion of silver flowed away with the medium and another reason is that a large amount of bacteria $\left(10^{6} / \mathrm{mL}\right)$ exists in the medium, which indicates harsh conditions. The T4-treated $\mathrm{Mg}$-Ag alloys got better antibacterial properties than pure $\mathrm{Mg}$. T4-treated Mg-8Ag released more silver (twofold) than T4-treated $\mathrm{Mg}$ $6 \mathrm{Ag}$, but bacteria viability decreased only by 4 percent due to the flow system of the bioreactor. In this case, lessreleased silver ions reacted with the bacteria attached to the surface of the discs. According to the decreasing trend of bacteria viability, if we continue to increase the silver content in pure $\mathrm{Mg}$, for example, $15 \mathrm{wt} \%$, more effective antibacterial properties of $\mathrm{Mg}$-Ag alloy could theoretically be achieved in the bioreactor. However, the degradation rate approaches its limit at an acceptable range for orthopedic implants [60].

Silver ions can bind strongly and build complexes with thiols, metallothionein, albumins, and macroglobulins in vivo $[29,61,62]$. The antibacterial properties of $\mathrm{Mg}-\mathrm{Ag}$ alloys are related to the silver concentration in the infection site, which is determined by the amount of silver in the $\mathrm{Mg}$-Ag alloys and its release rate. If only a small amount of silver was released, the remaining silver was not sufficient to inhibit bacteria. In contrast, if the amount of active silver ions released was greater, the antibacterial properties would be more effective [25], so it is better to alloy as much silver as possible in pure $\mathrm{Mg}$ to ensure effective antibacterial properties on the basis of a controllable degradation rate. However, the total silver in the Mg-Ag alloy should not exceed the amount that can cause argyria in the human body.

\section{Conclusion}

In this study, the relationship between the microstructure, silver content, degradation behavior, cytotoxicity, and antibacterial properties of $\mathrm{Mg}-\mathrm{Ag}$ alloys was revealed. The microstructure has a strong influence on the degradation 
behavior of Mg-Ag alloys. The degradation rate will be high if there are many precipitates in the $\mathrm{Mg}-\mathrm{Ag}$ alloys. To reach a lower degradation rate, the microstructure was adjusted via solution treatment (T4). As a result, precipitates dissolved into the magnesium matrix and the grains enlarged. T4treated $\mathrm{Mg}-\mathrm{Ag}$ alloys showed low degradation rate as pure $\mathrm{Mg}$ and more homogeneous degradation than pure $\mathrm{Mg}$. The T4-treated $\mathrm{Mg}-\mathrm{Ag}$ alloys had no discernible in vitro cytotoxicity to human primary osteoblasts compared with pure Mg. Moreover, the antibacterial properties depend on silver release. By increasing the silver content and controlling the degradation rate, the T4-treated $\mathrm{Mg}$-Ag alloys showed good antibacterial properties in the bioreactor system with flow conditions and abundant bacteria inside.

\section{Conflicts of Interest}

The authors declare that there is no conflict of interest regarding the publication of this paper.

\section{Acknowledgments}

Zhidan Liu thanks the financial support of CSC (China Scholarship Council). The authors would like to acknowledge Gábor Szakács for helping with casting and hot extrusion, Gabriele Salamon for the isolation of human primary osteoblasts, and Juliane Zirm for bacteria counting. During the sample preparation, Monika Luczak provided great assistance and Gert Wiese provided helpful support in the metallography preparation. The research leading to these results received funding from the Helmholtz Virtual Institute "In vivo studies of biodegradable magnesium based implant materials (MetBioMat)" under Grant agreement no. VH-VI-523.

\section{References}

[1] M. A. Olsen, J. J. Nepple, K. D. Riew et al., "Risk factors for surgical site infection following orthopaedic spinal operations," The Journal of Bone \& Joint Surgery, vol. 90, no. 1, pp. 62-69, 2008.

[2] G. Reid, "Biofilms in infectious disease and on medical devices," International Journal of Antimicrobial Agents, vol. 11, no. 3, pp. 223-226, 1999.

[3] A. Fernandes and M. Dias, "The microbiological profiles of infected prosthetic implants with an emphasis on the organisms which form biofilms," Journal of Clinical and Diagnostic Research, vol. 7, no. 2, p. 219, 2013.

[4] R. A. Brady, J. G. Leid, J. H. Calhoun, J. W. Costerton, and M. E. Shirtliff, "Osteomyelitis and the role of biofilms in chronic infection," FEMS Immunology \& Medical Microbiology, vol. 52, no. 1, pp. 13-22, 2008.

[5] P. Vergidis and R. Patel, "Novel approaches to the diagnosis, prevention, and treatment of medical device-associated infections," Infectious Disease Clinics of North America, vol. 26, no. 1, pp. 173-186, 2012.

[6] J. Gallo, M. Holinka, and C. S. Moucha, "Antibacterial surface treatment for orthopaedic implants," International Journal of Molecular Sciences, vol. 15, no. 8, pp. 13849-13880, 2014.

[7] H. Qin, H. Cao, Y. Zhao et al., "In vitro and in vivo anti-biofilm effects of silver nanoparticles immobilized on titanium," Biomaterials, vol. 35, no. 33, pp. 9114-9125, 2014.
[8] G. Song, "Control of biodegradation of biocompatable magnesium alloys," Corrosion Science, vol. 49, no. 4, pp. 1696-1701, 2007.

[9] D. A. Robinson, R. W. Griffith, D. Shechtman, R. B. Evans, and M. G. Conzemius, "In vitro antibacterial properties of magnesium metal against Escherichia coli, Pseudomonas aeruginosa and Staphylococcus aureus," Acta Biomaterialia, vol. 6, no. 5, pp. 1869-1877, 2010.

[10] H. Qin, Y. Zhao, M. Cheng et al., “Anti-biofilm properties of magnesium metal via alkaline $\mathrm{pH}$," RSC Advances, vol. 5, no. 28, pp. 21434-21444, 2015.

[11] M. I. Rahim, R. Eifler, B. Rais, and P. P. Mueller, "Alkalization is responsible for antibacterial effects of corroding magnesium," Journal of Biomedical Materials Research Part A, vol. 103, no. 11, pp. 3526-3532, 2015.

[12] G. Song and A. Atrens, "Understanding magnesium corrosion," Advanced Engineering Materials, vol. 5, no. 12, pp. 837-858, 2003.

[13] A. Nostro, L. Cellini, M. Di Giulio et al., "Effect of alkaline pH on staphylococcal biofilm formation," APMIS, vol. 120, no. 9, pp. 733-742, 2012.

[14] J. Zeng, L. Ren, Y. Yuan et al., "Short-term effect of magnesium implantation on the osteomyelitis modeled animals induced by Staphylococcus aureus," Journal of Materials Science: Materials in Medicine, vol. 24, no. 10, pp. 2405-2416, 2013.

[15] M. P. Staiger, A. M. Pietak, J. Huadmai, and G. Dias, "Magnesium and its alloys as orthopedic biomaterials: a review," Biomaterials, vol. 27, no. 9, pp. 1728-1734, 2006.

[16] F. Witte, J. Fischer, J. Nellesen et al., "In vitro and in vivo corrosion measurements of magnesium alloys," Biomaterials, vol. 27, no. 7, pp. 1013-1018, 2006.

[17] D. Xue, Y. Yun, Z. Tan, Z. Dong, and M. J. Schulz, "In vivo and in vitro degradation behavior of magnesium alloys as biomaterials," Journal of Materials Science \& Technology, vol. 28, no. 3, pp. 261-267, 2012.

[18] J. Walker, S. Shadanbaz, N. T. Kirkland et al., "Magnesium alloys: predicting in vivo corrosion with in vitro immersion testing," Journal of Biomedical Materials Research Part B: Applied Biomaterials, vol. 100, no. 4, pp. 1134-1141, 2012.

[19] R. J. White, "An historical overview of the use of silver in wound management," British Journal of Community Nursing, vol. 6, Suplement 1, pp. 3-8, 2001.

[20] L. Actis, L. Gaviria, T. Guda, and J. L. Ong, "Antimicrobial surfaces for craniofacial implants: state of the art," Journal of the Korean Association of Oral and Maxillofacial Surgeons, vol. 39, no. 2, pp. 43-54, 2013.

[21] H.-J. Park, J. Y. Kim, J. Kim et al., "Silver-ion-mediated reactive oxygen species generation affecting bactericidal activity," Water Research, vol. 43, no. 4, pp. 1027-1032, 2009.

[22] C. Marambio-Jones and E. M. Hoek, "A review of the antibacterial effects of silver nanomaterials and potential implications for human health and the environment," Journal of Nanoparticle Research, vol. 12, no. 5, pp. 1531-1551, 2010.

[23] R. O. Becker, "Silver ions in the treatment of local infections," Metal-Based Drugs, vol. 6, no. 4-5, pp. 311-314, 1999.

[24] S. Jacquart, R. Siadous, C. Henocq-Pigasse et al., "Composition and properties of silver-containing calcium carbonate-calcium phosphate bone cement," Journal of Materials Science: Materials in Medicine, vol. 24, no. 12, pp. 2665-2675, 2013.

[25] B. Hussmann, I. Johann, M. Kauther, S. Landgraeber, M. Jäger, and S. Lendemans, "Measurement of the silver ion 
concentration in wound fluids after implantation of silvercoated megaprostheses: correlation with the clinical outcome," BioMed Research International, vol. 2013, Article ID 763096, 11 pages, 2013.

[26] J. Hardes, A. Streitburger, H. Ahrens et al., "The influence of elementary silver versus titanium on osteoblasts behaviour in vitro using human osteosarcoma cell lines," Sarcoma, vol. 2007, Article ID 26539, 5 pages, 2007.

[27] A. Gettler, C. Rhoads, and S. Weiss, "A contribution to the pathology of generalized argyria with a discussion of the fate of silver in the human body," The American Journal of Pathology, vol. 3, no. 6, p. 631, 1927.

[28] H. Aoyagi and S.-i. Iwasaki, "Long-term effect of silver powder in vivo," Dental Materials Journal, vol. 27, no. 4, pp. 612-625, 2008.

[29] A. B. Lansdown, "A pharmacological and toxicological profile of silver as an antimicrobial agent in medical devices," Advances in Pharmacological Sciences, vol. 2010, Article ID 910686, 16 pages, 2010.

[30] L. E. Gaul and A. Staud, "Clinical spectroscopy: seventy cases of generalized argyrosis following organic and colloidal silver medication, including a biospectrometric analysis of ten cases," Journal of the American Medical Association, vol. 104, no. 16, pp. 1387-1390, 1935.

[31] J. W. Pifer, B. R. Friedlander, R. T. Kintz, and D. K. Stockdale, "Absence of toxic effects in silver reclamation workers," Scandinavian Journal of Work, Environment \& Health, vol. 15, no. 3, pp. 210-221, 1989.

[32] C. Baldi, C. Minoia, A. Di Nucci, E. Capodaglio, and L. Manzo, "Effects of silver in isolated rat hepatocytes," Toxicology Letters, vol. 41, no. 3, pp. 261-268, 1988.

[33] Y. S. Kim, M. Y. Song, J. D. Park et al., "Subchronic oral toxicity of silver nanoparticles," Particle and Fibre Toxicology, vol. 7, no. 1, p. 20, 2010.

[34] P. L. Drake and K. J. Hazelwood, "Exposure-related health effects of silver and silver compounds: a review," Annals of Occupational Hygiene, vol. 49, no. 7, pp. 575-585, 2005.

[35] R. O. Darouiche, "Treatment of infections associated with surgical implants," New England Journal of Medicine, vol. 350, no. 14, pp. 1422-1429, 2004.

[36] S. D. Puckett, E. Taylor, T. Raimondo, and T. J. Webster, "The relationship between the nanostructure of titanium surfaces and bacterial attachment," Biomaterials, vol. 31, no. 4, pp. 706-713, 2010.

[37] V. K. Truong, R. Lapovok, Y. S. Estrin et al., "The influence of nano-scale surface roughness on bacterial adhesion to ultrafine-grained titanium," Biomaterials, vol. 31, no. 13, pp. 3674-3683, 2010.

[38] M. Yoshinari, Y. Oda, T. Kato, and K. Okuda, "Influence of surface modifications to titanium on antibacterial activity in vitro," Biomaterials, vol. 22, no. 14, pp. 2043-2048, 2001.

[39] Y. Zhao, M. I. Jamesh, W. K. Li et al., "Enhanced antimicrobial properties, cytocompatibility, and corrosion resistance of plasma-modified biodegradable magnesium alloys," Acta Biomaterialia, vol. 10, no. 1, pp. 544-556, 2014.

[40] N. J. Hickok and I. M. Shapiro, "Immobilized antibiotics to prevent orthopaedic implant infections," Advanced Drug Delivery Reviews, vol. 64, no. 12, pp. 1165-1176, 2012.

[41] A. Nayeb-Hashemi and J. Clark, "The Ag-Mg (silver-magnesium) system," Bulletin of Alloy Phase Diagrams, vol. 5, no. 4, pp. 348-358, 1984.
[42] F. Feyerabend, H. Drücker, D. Laipple et al., "Ion release from magnesium materials in physiological solutions under different oxygen tensions," Journal of Materials Science: Materials in Medicine, vol. 23, no. 1, pp. 9-24, 2012.

[43] L. Yang, N. Hort, R. Willumeit, and F. Feyerabend, "Effects of corrosion environment and proteins on magnesium corrosion," Corrosion Engineering, Science and Technology, vol. 47, no. 5, pp. 335-339, 2012.

[44] F. Feyerabend, M. Johannisson, Z. Liu, and R. WillumeitRömer, "Influence of various sterilization methods on hardness, grain size and corrosion rate of a Mg6Ag-alloy," BioNanoMaterials, vol. 16, no. 1, pp. 51-58, 2015.

[45] S. Nagel-Heyer, C. Goepfert, F. Feyerabend et al., "Bioreactor cultivation of three-dimensional cartilage-carrier-constructs," Bioprocess and Biosystems Engineering, vol. 27, no. 4, pp. 273-280, 2005.

[46] L. Scorzolini, M. Lichtner, M. Iannetta et al., "Sonication technique improves microbiological diagnosis in patients treated with antibiotics before surgery for prosthetic joint infections," The New Microbiologica, vol. 37, no. 3, pp. 321-328, 2014.

[47] K. E. Piper, M. J. Jacobson, R. H. Cofield et al., "Microbiologic diagnosis of prosthetic shoulder infection by use of implant sonication," Journal of Clinical Microbiology, vol. 47, no. 6, pp. 1878-1884, 2009.

[48] M. Ribeiro, F. J. Monteiro, and M. P. Ferraz, "Infection of orthopedic implants with emphasis on bacterial adhesion process and techniques used in studying bacterial-material interactions," Biomatter, vol. 2, no. 4, pp. 176-194, 2012.

[49] A. Bogut, J. Niedźwiadek, D. Strzelec-Nowak et al., "Infectious prosthetic hip joint loosening: bacterial species involved in its aetiology and their antibiotic resistance profiles against antibiotics recommended for the therapy of implant-associated infections," The New Microbiologica, vol. 37, no. 2, pp. 209$218,2014$.

[50] H. Shen, J. Tang, Y. Mao et al., "Pathogenic analysis in different types of orthopedic implant infections," Chinese Medical Journal, vol. 127, no. 15, pp. 2748-2752, 2014.

[51] H. Rohde, E. C. Burandt, N. Siemssen et al., "Polysaccharide intercellular adhesin or protein factors in biofilm accumulation of Staphylococcus epidermidis and Staphylococcus aureus isolated from prosthetic hip and knee joint infections," Biomaterials, vol. 28, no. 9, pp. 1711-1720, 2007.

[52] F. Witte, V. Kaese, H. Haferkamp et al., "In vivo corrosion of four magnesium alloys and the associated bone response," Biomaterials, vol. 26, no. 17, pp. 3557-3563, 2005.

[53] Z. Li, X. Gu, S. Lou, and Y. Zheng, "The development of binary $\mathrm{Mg}-\mathrm{Ca}$ alloys for use as biodegradable materials within bone," Biomaterials, vol. 29, no. 10, pp. 1329-1344, 2008.

[54] F. Witte, N. Hort, C. Vogt et al., "Degradable biomaterials based on magnesium corrosion," Current Opinion in Solid State and Materials Science, vol. 12, no. 5, pp. 63-72, 2008.

[55] S. Zhang, X. Zhang, C. Zhao et al., "Research on an Mg-Zn alloy as a degradable biomaterial," Acta Biomaterialia, vol. 6, no. 2, pp. 626-640, 2010.

[56] D. Tie, F. Feyerabend, W.-D. Müller et al., "Antibacterial biodegradable Mg-Ag alloys," European Cells and Materials, vol. 25, pp. 284-298, 2013.

[57] E. Ghali, W. Dietzel, and K.-U. Kainer, "General and localized corrosion of magnesium alloys: a critical review," Journal of Materials Engineering and Performance, vol. 13, no. 1, pp. 7-23, 2004. 
[58] J. Fischer, D. Pröfrock, N. Hort, R. Willumeit, and F. Feyerabend, "Reprint of: improved cytotoxicity testing of magnesium materials," Materials Science and Engineering: B, vol. 176, no. 20, pp. 1773-1777, 2011.

[59] T. R. Garrett, M. Bhakoo, and Z. Zhang, "Bacterial adhesion and biofilms on surfaces," Progress in Natural Science, vol. 18, no. 9, pp. 1049-1056, 2008.

[60] C. Seal, K. Vince, and M. Hodgson, Biodegradable Surgical Implants Based on Magnesium Alloys-A Review of Current Research, IOP Conference Series: Materials Science and Engineering, p. 012011, IOP Publishing, Bristol, England, 2009.

[61] V. K. Sharma, K. M. Siskova, R. Zboril, and J. L. GardeaTorresdey, "Organic-coated silver nanoparticles in biological and environmental conditions: fate, stability and toxicity," Advances in Colloid and Interface Science, vol. 204, pp. 15-34, 2014.

[62] N. Shahabadi, M. Maghsudi, and Z. Ahmadipour, "Study on the interaction of silver (I) complex with bovine serum albumin by spectroscopic techniques," Spectrochimica Acta Part A: Molecular and Biomolecular Spectroscopy, vol. 92, pp. 184-188, 2012. 


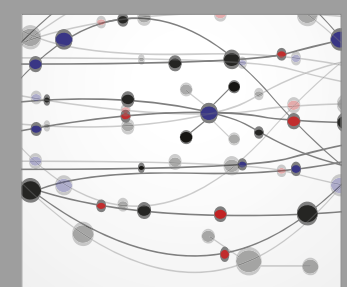

The Scientific World Journal
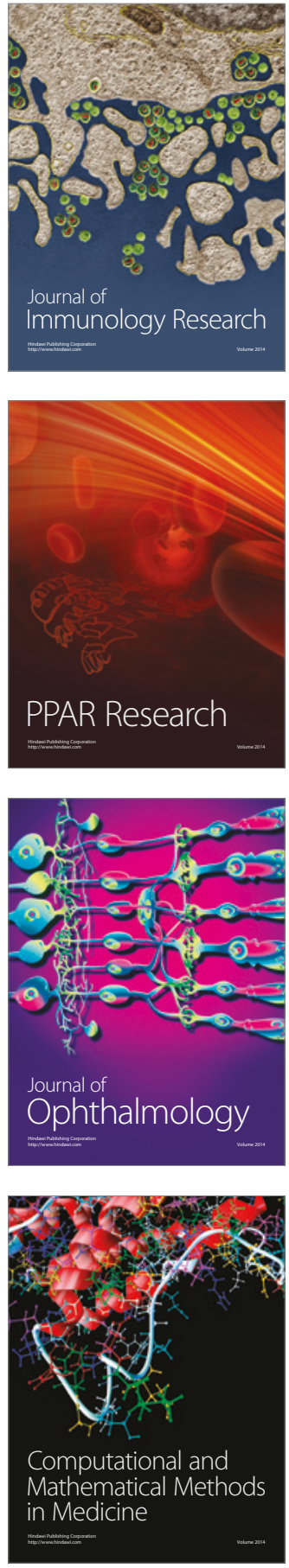

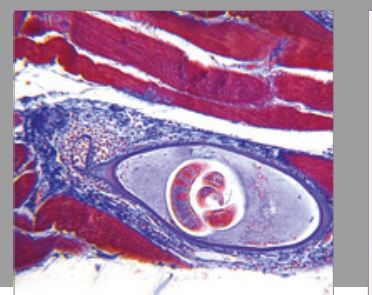

Gastroenterology Research and Practice
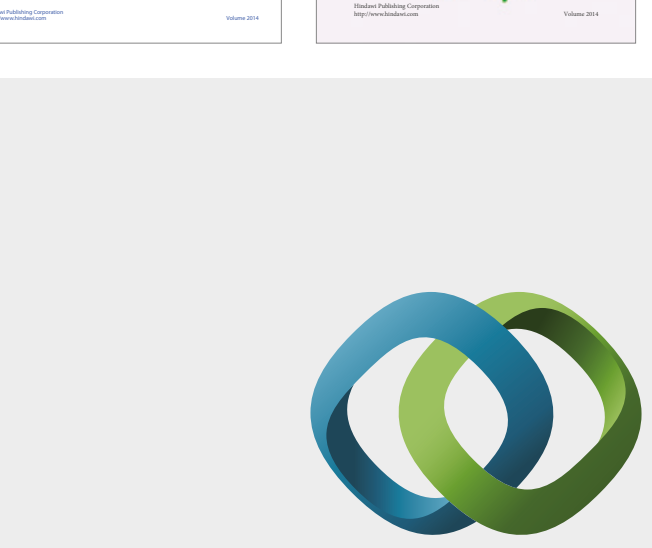

\section{Hindawi}

Submit your manuscripts at

https://www.hindawi.com
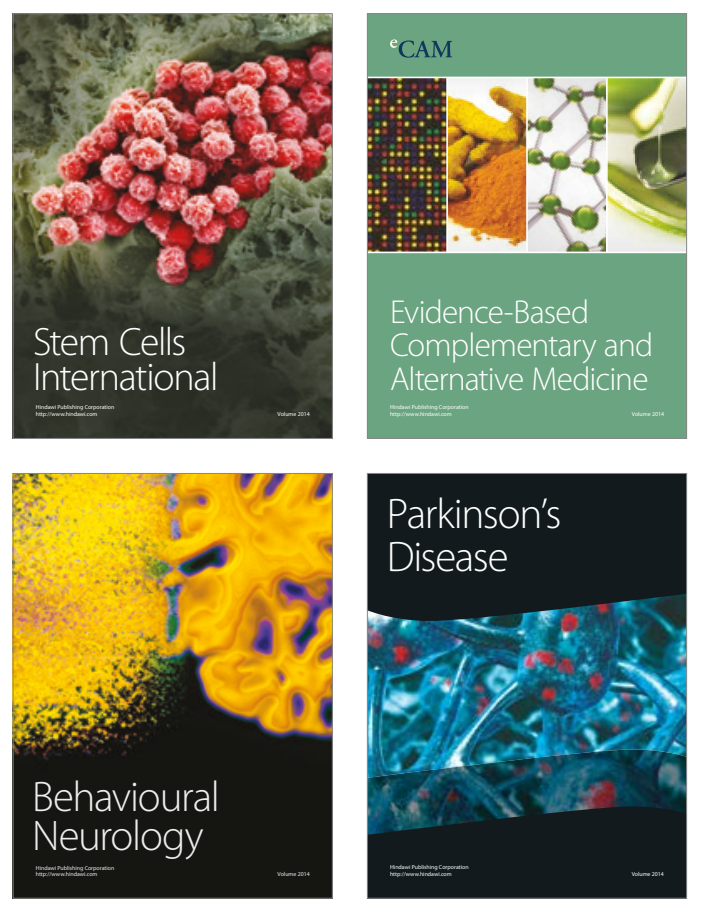
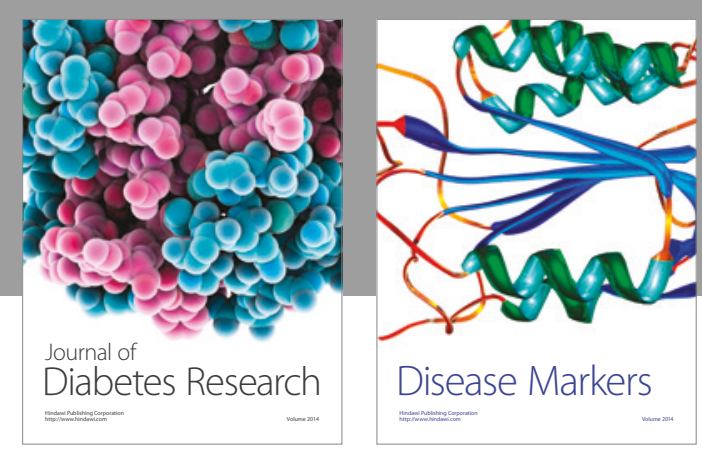

Disease Markers
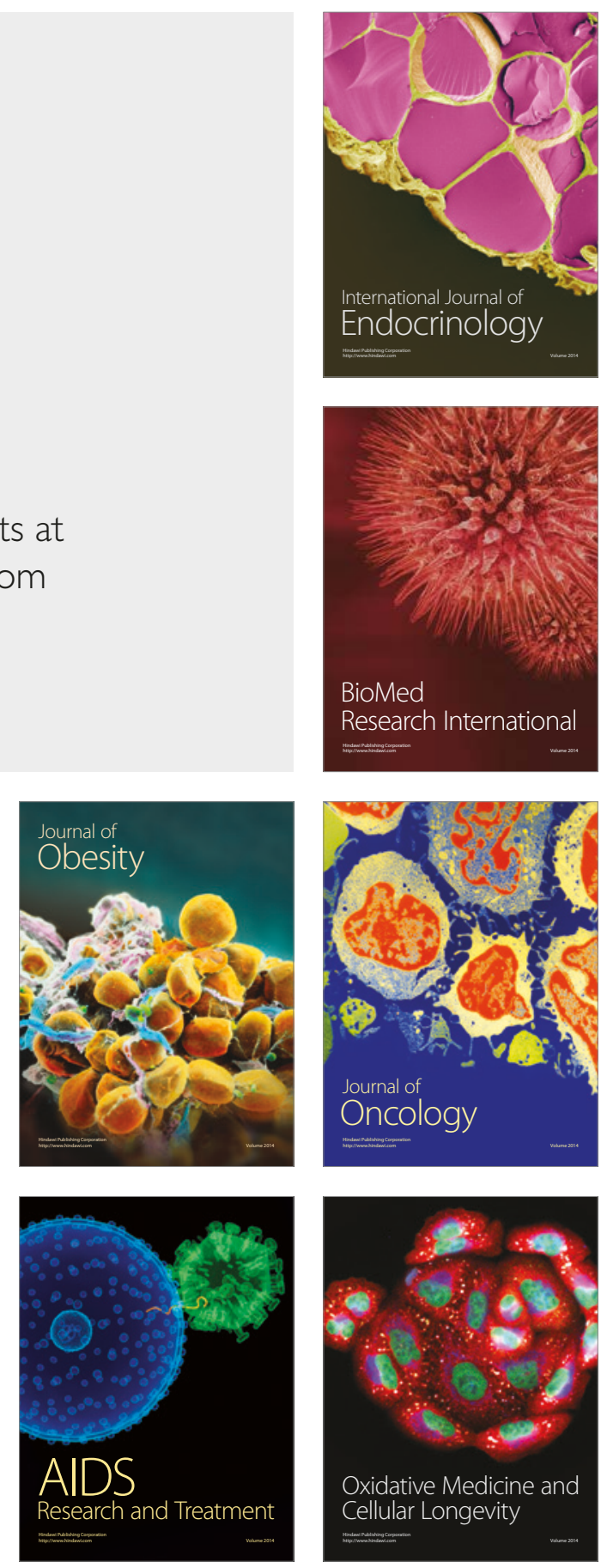